\title{
The value of communication: Evidence from a field experiment with entrepreneurs in Togo
}

\author{
Stefan Dimitriadis \\ Rotman School of Management \\ University of Toronto \\ stefan.dimitriadis@rotman.utoronto.ca \\ Rembrand Koning \\ Harvard Business School \\ Harvard University \\ rem@hbs.edu
}

September 20, 2019

Why do some entrepreneurs benefit from their portfolio of peer advisers while others do not? In this study, we argue that communication practices are an important but overlooked factor in the formation of useful advice relationships between entrepreneurs, particularly in the context of developing economies. We hypothesize that improving entrepreneurs' communication practices will affect the relationships they form and have implications for their business performance. To test our theory, we conducted a field experiment in Togo with 301 entrepreneurs who were randomized into a communication practices intervention that was embedded in a business training program. We found that entrepreneurs who were exposed to better communication practices perceived interactions more cooperatively and exchanged more information during those interactions. Moreover, improving communication practices also led to a 50 percent increase in the number of relationships entrepreneurs formed with peers. These relationships exhibited more matching based on skill and were more ethnically diverse. Finally, communication practices training also substantially increased entrepreneurs' business performance. Our findings highlight how communication practices play a central role in entrepreneurs' ability to form portfolios of relationships and perform in challenging business environments.

Keywords: communication practices, entrepreneurship, business relationships, developing country, field experiment

We thank Julie Battilana, Laura Doering, Soléne Délécourt, Anita McGahan; Sharique Hasan, Peter Marsden, MaryHunter McDonnell, Will Mitchell, Aruna Ranganathan, Metin Sengul, and Ned Smith for helpful feedback and suggestions. We also thank Alaye Abalo, Essenam Agblevo, Ayite Eklu, Matt Thibek, and Nyaku Yao for excellent research assistance. This project has received funding from Harvard Business School, the Kauffman Foundation Dissertation Fellowship, and the Strategic Research Foundation's Dissertation Fellowship Program. 


\section{INTRODUCTION}

Entrepreneurs depend on access to information to seize opportunities, find employees, and develop new products. This information is all the more crucial in developing countries, where formal institutions that encourage information flows are often weak. Therefore, a key challenge for entrepreneurs in developing countries is how to access new, accurate, and timely information.

Prior research has highlighted that advice from peers can help entrepreneurs resolve this problem of information access (Zuckerman and Sgourev, 2006; Kacperczyk, 2013; Abraham, 2019). Relationships with peers can serve as important sources of information about how to manage a business, identify market opportunities, and learn new practices (Sorenson, Rivkin, and Fleming, 2006; Stuart and Ding, 2006; Chatterji et al., 2018). However, research also suggests that entrepreneurs' portfolios of peer relationships are frequently far from optimal in terms of providing access to information. Rather, entrepreneurs' peer relationships tend to be made up of people who are similar to them (Ingram and Morris, 2007; Vissa, 2011), in physical proximity (Aldrich and Kim, 2007), or family members (Peng, 2004). These types of peers, by virtue of their similarity to the focal entrepreneur, are less likely to provide access to new or timely information (Granovetter, 1973; Reagans and Zuckerman, 2008). Given the value of peer advice, how can entrepreneurs improve the size and composition of their portfolios of advisers?

We argue that communication practices can help entrepreneurs identify more and better advisers, build relationships with them, and so improve business performance. By making it easier to engage with and share information with strangers, communication practices enable entrepreneurs to form relationships on the basis of useful information instead of relying on signals like homophily or proximity. Similar to how organizations adopt practices to improve internal communication flows (Allen, 1966; Goffman, 1967; Tushman, 1978; Collins, 2004), we argue that entrepreneurs can also improve their communication practices. We build on theories of organizational communication, as well as practitioner insights, to identify three practices that enable entrepreneurs to connect with and learn from peers: (1) asking questions and giving advice; (2) reflecting on others; and (3) following up. 
We use a field experiment in Togo to test if improving communication practices leads entrepreneurs to better exchange information and build more useful peer relationships. Togo is a suitable setting to test this theory because local conditions make communication between entrepreneurs especially difficult. Based on 47 semistructured interviews with entrepreneurs in Togo, we found evidence that while entrepreneurs were aware of the benefits of peer advice, most struggled to initiate and sustain communication with their peers. To test if better communication practices would help overcome these difficulties, we worked with a business training program to develop a two-hour communication practices intervention. Crucially, we randomized which cohorts received this additional training. The experimental design allows us to separate the impact of communication practices from observed and unobserved differences in an entrepreneurs' network composition and business ability. In total, 301 entrepreneurs enrolled in the program, roughly half of whom received the intervention. Entrepreneurs were surveyed at the start of the training program, at the end of the program, six weeks after the program, and six months after the program.

Results from our analyses show that, even when limited to a brief introduction, teaching communication practices leads to a cascade of changes in entrepreneurs' patterns of interaction and relationships. First, we argue that training in communication practices make prospective interactions with other entrepreneurs more appealing because they increase entrepreneurs' expectations of gaining new information. As a result, entrepreneurs' perceptions of interactions and their level of engagement in them should improve. Indeed, we find that entrepreneurs in the treatment condition of the field experiment were significantly more likely to perceive interactions as cooperative and also engaged in significantly more information exchange during those interactions.

This effect on interactions should in turn change the patterns of relationship formation. With more information and a stronger sense of how to engage with others, entrepreneurs with better communication practices are more likely to identify more individuals who they want to learn from, who have complementary skills, and who they want to sustain relationships with. Consistent with this logic, our analyses show that entrepreneurs who received the treatment formed approximately 50 percent more new relationships and that they formed advice 
relationships based on business needs rather than similarity on ascriptive characteristics. Specifically, we find that entrepreneurs in the treatment condition formed more relationships with peers possessing skills they wanted to learn and also ended up with more ethnically diverse ties.

Finally, through a combination of the information gained and the new relationships formed, we expect entrepreneurs to seize more market opportunities and improve their business practices. This, in turn, should drive improvements in business performance. Accordingly, we found that six months after the training program entrepreneurs in the treatment group increased their performance by approximately 50 percent compared with the control group.

This study makes three main contributions. First, it contributes to existing research on interorganizational communication. Although this area of research has deep roots in sociology and organization theory (Goffman, 1967; Tushman, 1978; Allen, 1984; Collins, 2004), recent research on organizations and entrepreneurship has generally abstracted from individual interactions and the process of communication (McFarland, Jurafsky, and Rawlings, 2013). Bringing communication into focus is a salient contribution, particularly as organization theory begins to consider environments where communication about business is difficult, such as in developing countries. Our theory of communication practices provides a new lens for thinking about the impact of relationships both between and within organizations.

Second, this study contributes to the literature on business relationship formation in entrepreneurship. There is a plethora of research on the ways in which dyad-level characteristics affect the process of relationship formation (Hallen, 2008; Vissa, 2012; Kleinbaum, Stuart, and Tushman, 2013) and their consequences for entrepreneurial performance (Stuart and Sorenson, 2007). This study considers a new factor that affects patterns of relationship formationcommunication practices - and provides causal evidence of their benefits for entrepreneurs' business relationships.

Finally, this study also contributes to research on entrepreneurship in developing countries. There is a growing body of research that aims to understand how entrepreneurs operating in 
resource-scarce and institutionally challenging settings can build business relationships and increase their performance (Dutt et al., 2016; Assenova and Sorenson, 2017; Pierce and Snyder, 2017). Our findings suggest that communication practices may be particularly valuable in these environments, as they help entrepreneurs overcome challenges created by weak formal institutions and increase their business performance (Khanna and Palepu, 2010; Gao et al., 2017).

\section{ENTREPRENEURSHIP AND COMMUNICATION PRACTICES}

Entrepreneurs tend to rely on peer advice relationships to access important information about markets (e.g., new opportunities), learn about business practices, find clients, and hire employees (Saxenian, 1990; Zuckerman and Sgourev, 2006; Cai and Szeidl, 2017). This is especially the case in developing countries, where formal market institutions that act as alternative sources of such information may be lacking (Nanda and Khanna, 2010; Acquaah, 2012; Armanios et al., 2017). Yet many entrepreneurs in developing economies have portfolios of peer relationships that do not maximize access to information. Rather, they are heavily homophilous, often segregated by ethnic group and reliant on family members, neighbors, or others who work nearby (Ruef, Aldrich, and Carter, 2003; George et al., 2016b). While high in trust, the drawback of these closed relationships is that they provide less access to new information about markets (Renzulli, Aldrich, and Moody, 2000). Individuals who are similar and come from the same environment are likely to know more or less the same things or find out about them at the same time as the focal entrepreneur (Granovetter, 1973; Burt, 1992; Golub and Jackson, 2012).

This homophilous composition of peer relationship portfolios is driven at least in part by the fact that communication with similar others is often easier (McPherson, Smith-Lovin, and Cook, 2001). Individuals with similar experiences and who occupy similar social spheres perceive the world in similar ways, which makes communication between them less complicated (Zenger and Lawrence, 1989; Kleinbaum, Stuart, and Tushman, 2013). By contrast, communication with dissimilar alters is a more complex because there is less of a shared vocabulary or repository of common experiences. As a result, part of an entrepreneurs' challenge with forming larger and 
more diverse relationships relates to their ability to communicate effectively about business issues with others. Put simply, communication between entrepreneurs without a shared background is difficult.

Research on organizations has long recognized that this is also the case with communication within organizations (Katz and Kahn, 1978; Allen, 1984). In the case of intra-organizational communication, prior work has identified many of the challenges involved in exchanging information. Employees from different demographic and functional backgrounds often lack shared codes or a common language, and fail to ask of and listen to one another (Edmondson, Bohmer, and Pisano, 2001; Weber and Camerer, 2003; Huang et al., 2017). Yet communication need not break down. Work building on these insights argues that planned, structured, and formalized patterns of communication within organizations enable interactions between individuals and facilitate the transfer of information, thereby improving business performance (Allen and Cohen, 1969; Tushman, 1979). For example, Lee et al. (2019) find that teams within a consulting firm relied on the communication practice of using interaction scripts to facilitate communication during interactions. Similarly, Kellogg et al.'s (2006) study of a marketing agency revealed that cross-boundary communication practices were needed for employees to communicate and coordinate effectively.

We argue that, similar to organizations, there exists a bundle of practices that can improve the quality and quantity of entrepreneurial communication. For entrepreneurs, these practices are centered on three mechanisms in the communication process that tend to break down: sharing information, identifying complementary others, and sustaining communication once started. Below we describe how each of these three mechanisms makes communication difficult and then link each to practices that scholars and practitioners have argued might overcome these challenges.

Information sharing. When attempting to communicate, entrepreneurs commonly fail because they don't talk about businesses in the same way. As a result, they have difficulty conveying what their business does, the issues they face, and their visions for the future. This failure relates to foundational insights about communication and the need for both parties to have shared codes 
and collections of terms, symbols, anecdotes, and statements (Allen and Cohen, 1969; Tushman and Katz, 1980). Individual entrepreneurs carry their own sets of codes, which may diverge significantly between otherwise similar peers (Weber and Camerer, 2003).

Developing a shared understanding about others' businesses requires a process of asking questions and offering advice. Asking questions is something that individuals frequently fail at, particularly when it comes to questions that sustain a conversation and probe into others' businesses (Huang et al., 2017; Brooks and John, 2018). But question asking is critical because it allows entrepreneurs to understand the way others' businesses operate, the problems they face, and the language they use to describe it (Hasan and Koning, 2019a). As Simon (1991:131) stressed, "Each [actor] must have a sufficient knowledge and understanding of the others' problems to be able to communicate effectively."

These theoretical insights are closely paralleled by practitioner recommendations that advise entrepreneurs to ask questions and give advice as part of the communication process. Expressing genuine curiosity through questions can begin a process of learning about others' businesses (Argyris, 1991). Giving advice also helps entrepreneurs learn how to talk about their business and how to effectively use those terms themselves (Rollag, 2015; Casciaro, Gino, and Kouchaki, 2016). Sharing advice not only encourages asking more questions, it also pushes entrepreneurs to translate their own information into others' terms (Uzzi and Dunlap, 2005; Ibarra and Hunter, 2007).

Identifying complementary others. Even when entrepreneurs are able to share information, it may be of little use if they cannot identify those who have new or relevant information. This can frequently be an issue, as network theory suggests people tend to gravitate toward others who are similar to them in terms of ascriptive characteristics such as age, gender, or ethnicity (McPherson, Smith-Lovin, and Cook, 2001; Ingram and Morris, 2007). The danger with associating based on ascriptive similarity is that the exchange partner may have access only to relatively similar information as the focal entrepreneur and, as result, may not have new and complementary information to share. 
According to research, going beyond homophily or proximity requires that entrepreneurs identify alters with new, non-redundant information. Burt and Ronchi (2007) suggest that teaching network concepts like brokerage and warning against stereotyping can lead to such improvements. Reagans et al. (2004) argue that merely seeking out others with different demographic characteristics may suffice for increasing individuals' network range and access to new information. In either case, there is a requirement that entrepreneurs shift toward reflecting on what their opportunity set of interactions is and which of those interactions may have the highest potential to help them achieve their goals.

The practitioner literature echoes these insights by emphasizing that entrepreneurs should look beyond their regular exchange partners and that they can do this by reflecting on others. This means taking the time to observe others in a given social setting, and to reflect on what they do and how that relates to their goals as entrepreneurs (Edmondson, 2012). The process of reflection helps identify others who potentially have useful information (Cross and Thomas, 2011). Taking the time to reflect on these issues can help reduce entrepreneurs' reliance on superficial similarities, proximity, or convenience when choosing whom to connect with (Krackhardt and Hanson, 1993; Cross et al., 2001). Thus, the practice of reflecting on others should help entrepreneurs identify more opportunities for communication.

Sustaining communication. Finally, communication may fail because it is fleeting. For communication to lead to the transfer of new and complex information, there must be sufficient interaction. Yet there is significant evidence that individuals tend to reach out to familiar alterspeople they already know well - rather than talk to people they've only recently met, because the latter requires more effort (Ingram and Morris, 2007; Hasan and Koning, 2019b). Failure to sustain communication, therefore, is a potential pitfall.

Research suggests that entrepreneurs can address this issue by communicating in a manner that creates opportunities for future interactions (Dahlander and McFarland, 2013). Repeated communication is at the foundation of cooperation (Baldassarri, 2015) because it enables the development of positive affect and trust (Homans, 1961; Feld, 1981). Integrating this into communication practices involves making communication a cyclical and endogenous process, 
with a propensity to repeat itself. The practitioner literature on communication places a lot of emphasis on opportunities for following up, particularly before the focal entrepreneur is in need of an alter's help (Casciaro and Lobo, 2005). It also involves searching for and emphasizing commonalities between the actors, which are likely to give rise to future opportunities for interaction (Uzzi and Dunlap, 2005). These recommendations suggest ending communications by explicitly setting up an opportunity to follow up in the future (Eisenhardt and Galunic, 2000).

To summarize, theory about inter-organizational communication, relationship formation, and entrepreneurship suggests that communication between entrepreneurs is a difficult task and is likely to fail at three different points: attempting to share information, identifying complementary alters, and sustaining communication. Practitioner insights suggest that there are communication practices that can help address these common failures for entrepreneurs. These are: asking questions and giving advice, reflecting on others, and following up. In the following section, we outline the ways in which teaching these communication practices affects measurable entrepreneurial outcomes.

\section{THE EFFECTS OF GOOD COMMUNICATION PRACTICES FOR ENTREPRENEURS}

Improving communication practices can have a series of cascading effects for entrepreneurs, beginning with their perceptions of and engagement in interactions, then affecting their formation of new relationships, and finally influencing their business performance.

Cooperation and information transfer. Communication practices are likely to be especially important in driving cooperative perceptions of interactions with other entrepreneurs. This is important because, compared with coworkers, entrepreneurs are more likely to be in direct product-market competition with one another. Moreover, in developing-country contexts, weaker formal market institutions and protections may increase uncertainty and entrepreneurs' perceptions of others as threats (Neace, 1999; Kim and Li, 2014). 
Communication practices can affect the extent to which entrepreneurs perceive interactions as cooperative in at least two ways. First, by structuring and adding formalization to the process of interaction between entrepreneurs, there is less ambiguity and room for error in the process. This reduces entrepreneurs' uncertainty and fear of engaging with others. Second, part of good communication is asking questions and giving advice, which are collaborative activities. These activities are known to inspire positive affect and a stronger sense of closeness between individuals (Small, 2009). For these reasons, entrepreneurs with better communication practices are more likely to perceive interactions with others as cooperative. We therefore hypothesize that:

Hypothesis 1a: Improving communication practices will lead entrepreneurs to perceive interactions as more cooperative than competitive.

Entrepreneurs' shift in their perception of interactions is paralleled by a shift in the way they share information in interactions. Better communication practices should enable entrepreneurs to exchange more information related to their businesses during interactions. First, the shift to more cooperative perceptions leads to a greater willingness to share knowledge, ask for advice, and give feedback. Second, communication practices emphasize asking questions and reflecting on which others have useful information. These practices direct entrepreneurs to focus on the reciprocal exchange of help and advice, which should increase the quantity of information about business that is exchanged. Finally, communication practices highlight how to more effectively sustain a conversation once started. With more back-and-forth, the interaction should help entrepreneurs better understand one another and so exchange more information. We therefore hypothesize that:

Hypothesis 1b: Improving communication practices will lead entrepreneurs to exchange more information during interactions.

Relationship formation. Interactions that are more cooperative and lead to greater information exchange should in turn increase the probability of forming a longer-term relationship. Increased cooperation and information exchange increase the perceived value of staying in touch with a 
peer. Moreover, a key component of better communication practices is the focus on sustaining communication over repeated interactions. Not only are entrepreneurs with better practices more likely to meet and interact with more people, they should also be better equipped to generate follow-up interactions with those people with whom they want to stay in touch. Thus, communication practices should result in richer interactions and the formation of more relationships. We therefore hypothesize that:

Hypothesis 2a: Improving communication practices will lead entrepreneurs to form more new relationships.

Skill complementarity. An important concern with any intervention that increases entrepreneurs' business relationships is that the intervention might lead to redundant business ties and unhelpful connections. We argue that, unlike mixers or other structural interventions (Ingram and Morris, 2007; Carrell, Sacerdote, and West, 2013), improving communication practices will result in the formation of fewer redundant business relationships, even though such practices push entrepreneurs to form more connections. Entrepreneurs with better communication practices form fewer redundant business relationships because they base their decision on more information about their peers. Better communication practices lead to more information transfer in any given interaction, and with more information, entrepreneurs can better evaluate the potential value of connecting with a peer (Hansen, Podolny, and Pfeffer, 2001; Kuwabara, Hildebrand, and Zou, 2018). Conversely, entrepreneurs can also better recognize when they have useful knowledge to share with their partner.

These arguments suggest that improved communication practices should not just increase the number of relationships, but also the quality of the match between any given pair. A first-order concern for entrepreneurs, especially in developing countries, is the acquisition of better management skills and practices (McKenzie and Woodruff, 2018). If communication improves matching, then we expect that entrepreneurs who communicate better will be more likely to connect with peers who have complementary skills they want to learn and, conversely, they possess a skill the peer would like to learn. Building on Vissa's (2011) concept of task complementarity, we define skill-complementary business relationships as those that connect an 
entrepreneur with another entrepreneur who possesses a management skill that the focal entrepreneur has expressed a desire to learn. This leads us to predict:

Hypothesis 2b: Improving communication practices will lead entrepreneurs to form more skillcomplementary relationships.

Ethnic diversity of relationships. If entrepreneurs are forming connections on the basis of skill complementarity, then what dimensions are they no longer building relationships on? As described earlier, an important pattern in relationship formation is homophily (McPherson, Smith-Lovin, and Cook, 2001). People who are similar in terms of ascriptive characteristics, such as ethnicity, are likely to communicate more easily, which makes the formation of a relationship between them likelier. Ethnicity is a particularly salient dimension of homophily in many African countries, which are often ethnically diverse (Easterly and Levine, 1997; Luke and Munshi, 2006; Yenkey, 2015; Pierce and Snyder, 2017). We argue that improved communication practices should diminish the role of ethnic homophily in the formation of relationships. Entrepreneurs who have been taught better communication practices might be less reliant on demographic similarity and other forms of non-deliberative matching, which occurs when actors match on a small, limited number of attributes (Azoulay, Liu, and Stuart, 2017). As a result, entrepreneurs will form more new relationships based on skill complementarity and access to new information rather than demographic similarity, which should lead to entrepreneurs forming more ethnically diverse relationships. This leads us to predict:

Hypothesis 2c: Improving communication practices will lead entrepreneurs to form relationships that are less concentrated in one ethnic group.

Entrepreneurial performance outcomes. Existing research suggests that entrepreneurs with larger and more diverse sets of business relationships are likely to perform better in terms of their survival, financing, and profitability (Shane and Cable, 2002; Chatterji et al., 2018). This happens because diverse business relationships provide access to information about market opportunities, increase the chance that an entrepreneur will come across a valuable new practice, and provide better access to resources such as funding and investments (Hochberg, Ljungqvist, 
and $\mathrm{Lu}, 2007)$. Given that entrepreneurs with better communication practices are likely to share more information and form more new relationships that are skill-complementary, we would expect that this leads to improvements in their business performance. We therefore predict that:

Hypothesis 3: Improving communication practices will improve entrepreneurs' business performance.

We expect performance to improve precisely because improved communication practices shift so many key mechanisms simultaneously. While this improves our confidence in Hypothesis 3, it does make it difficult to say precisely whether one single mechanism accounts for the change. For example, changes in communication practices will affect the information gained during one-

off interactions. They also change the number and diversity of relationships. Such changes might lead an entrepreneur to learn a new practice or to the referral of a new customer, and could lift benchmarks and expectations about appropriate levels of performance. It is likely that some combination of all of these effects works to benefit entrepreneurs and translates into higher performance. As a result, although we are able to hypothesize that exposure to good communication practices is likely to increase performance, we defer on identifying which of the mechanisms outlined in Hypotheses 1 and 2 are most responsible for shifts in performance. In the next section, we turn to where effective communication practices are likely already in use and where there might be room for improvement.

\section{Persistent Barriers to Adopting Better Communication Practices: The Case of Entrepreneurship in Togo}

Despite the apparent simplicity of communication practices, some environments may present persistent barriers to their use. While these practices may already be widely diffused and have become the norm in places like Silicon Valley or Route 128 (Hallen and Eisenhardt, 2012), there is reason to believe that this may not be the case in developing economies. Research on management practices has found that there are significant barriers to entrepreneurs using managerial best practices in developing countries (McKenzie and Woodruff, 2013). This work 
argues that many entrepreneurs are either unaware of the practices or lack motivation to implement them even if they are profitable (Gibbons et al., 2010; Bloom et al., 2013). In the case of communication practices, there may be similar reasons why entrepreneurs fail to implement them.

Given our focus on testing the effects of improving communication practices, we sought an empirical setting where barriers to communication would be prevalent. In the end, we selected Togo as a promising field site. Togo is a small, francophone country in West Africa and representative of countries designated by the World Bank as low-income. According to the "Doing Business Index" created by the World Bank to measure the difficulty involved in starting and operating a business, Togo scored 54.9 out of 100, which is close to the regional subSaharan average of 52.6 (World Bank, 2018). Although agriculture is the largest sector of economic activity, entrepreneurship rates have been rapidly increasing, particularly in urban areas, where the government has been promoting entrepreneurship as a solution to unemployment (Acs, Desai, and Hessels, 2008).

To better understand how our theory of communication practices maps onto the context of Togo, one of the authors conducted extensive fieldwork between 2015 and 2017. During three separate visits, this author conducted 47 semistructured interviews with entrepreneurs of varying levels of experience and in a variety of sectors of activity. Additional details about these interviews can be found in Appendix A. We used these interviews to understand how entrepreneurs perceived and engaged in communication. Our examination of the qualitative data showed that they were often aware of the value of peers and faced challenges in interacting, but they were often unaware of communication practices that could help overcome those challenges. This was expressed, unprompted, during several interviews as frustration with attempts at initiating and sustaining communication with other entrepreneurs. Several entrepreneurs admitted that although they were motivated to reach out to others, they simply felt that they couldn't initiate communication with them. For example, one entrepreneur said: 
I find that the way we are educated here is that entrepreneurs have good ideas but they cannot implement them because they cannot approach other people to discuss them. (YE 13)

Another entrepreneur expressed similar challenges related to reaching out to peers for the first time, when such attempts were hampered by the peers not having any "contact information" or not responding at all:

I find that to get help in Togo is complicated because there's no contact information, really. There are no real contacts, because you reach out to people through their emails and their websites, but you never get a response. Similarly, you deposit letters to request a meeting and it's as if you never did anything. It's frustrating. (YE 12)

When trying to understand why these difficulties in communication exist, entrepreneurs often turned to cultural narratives related to a lack of training in communication: They couldn't communicate effectively because local circumstances didn't train them to engage with other entrepreneurs. One expressed it like this:

I think you have to train yourself in order to form new relationships. There may be a cultural side that plays a role. For example, culturally, we go to the market, and the process of entrepreneurship that we have always known is seeing our mothers at the market. It's essentially that - it's customers coming to them and them never really having worked on a business strategy to attract customers. But it is also perhaps a lack of training on this [building relationships]! Existing entrepreneurial training focuses on the business plan and the sources of financing that may exist—loans or something like that — but not enough on the relational side. (YE 6)

Another entrepreneur expressed the same narrative from a different perspective, as related to mentors: 
[...] entrepreneurs here are not able to reach out to people. Even mentors tell you not to talk to others about your business. All this slows down the evolution of your business. (YE 4)

A seasoned entrepreneur, who had mentored younger entrepreneurs in Togo, lamented about how difficult it was to get entrepreneurs to talk to each other:

It's very difficult ! Entrepreneurs prefer to work alone, unfortunately. But our job is that too: to be able to sensitize them, train them, explain to them the merits of living together and working together. (AY 3)

The interviews revealed that Togo is a context where entrepreneurs are motivated to connect with peers, but also a place where they struggle to do so. Given the baseline difficulties in communication, changes in the exposure to communication practices should have measurable impacts.

\section{EXPERIMENTAL METHODS}

\section{Research Setting: “Marketing in Action” Business Training Program}

To study the impact of communication practices, we worked with a business training program for entrepreneurs in Togo's capital, Lomé. The context of the program allowed us to shift communication practices by exposing participants to a bundle of communication practices. The business training program was organized by the Association of Young Entrepreneurs of Togo (Association des Jeunes Entrepreneurs Togolais) in collaboration with the Energy Generation Academy. Both organizations are leading not-for-profit organizations in Togo whose social mission is the promotion of entrepreneurship. Both have extensive experience hosting business plan competitions and training events for entrepreneurs. In the spring of 2017, they invited entrepreneurs to participate in a training program called "Marketing in Action." In collaboration 
with the organizers, we created an experimental intervention to expose entrepreneurs to basic communication practices. We randomly selected half of the participating cohorts of entrepreneurs into this "communication practices" condition. ${ }^{1}$

\section{Participating Entrepreneurs and Randomization}

The Marketing in Action program solicited participants from throughout Lomé. The program was advertised to the local business community through social media and a network of local notfor-profit organizations. In addition to advertising, a team of three canvassers visited businesses door-to-door in all major commercial districts to invite the owners to participate. The requirements for participation were that the entrepreneurs had been in operation for at least one year and that they be based in the city of Lomé. In addition, participants were asked to pay a small participation fee (approximately 5 USD), which was reimbursed to them upon successful completion of the training. All of the entrepreneurs who participated in the training were both owners and founders of their businesses.

The recruitment process yielded 326 participants, whom we split into 14 groups, each with 2025 entrepreneurs. $^{2}$ Program dates were filled one after the other on a sequential basis as individuals registered. Once all the groups had been filled, 7 of the 14 groups were randomly selected into the communication practices condition using a random number generator in Excel. The timeline and implementation of the field experiment are detailed in Appendix A.

It is worth noting that the sample of entrepreneurs who participated in the field experiment is made up of those who decided to attend the training program on marketing practices. As a result, the sample is not completely representative of all enterprises in Togo. Due to this self-selection into the training program, the treatment effect of the field experiment applies to entrepreneurs who are motivated enough to participate in business training programs. Although this is a

\footnotetext{
${ }^{1}$ The surveys, intervention, and randomization were approved by the authors' Institutional Review Board (IRB) (Protocol \# IRB17-0319).

${ }^{2}$ Ex-post power calculations based on our study's sample of 301 observations and the cluster randomized trial design with 14 clusters have $91 \%$ power to detect an effect of the size we observe using a $5 \%$ significance level. This level of power is standard in research on entrepreneurship in strategy; see, for example, Chatterji et al. (2018), who use a field experimental design with entrepreneurs and have a similar sample size.
} 
boundary condition for this study, motivated entrepreneurs are also theoretically important because they are likelier to be key players in their market segments.

\section{Business Training Content and Instructors}

The training program curriculum was adapted from programs carried out by the International Labor Organization (ILO) in developing countries (for a review, see McKenzie and Woodruff (2013)). Typically, these programs bring together business owners for short courses on basic management practices. The Marketing in Action program used the ILO training course on marketing for small business owners, called the "Start and Improve Your Business Programme" (ILO 2018). The content covered seven basic marketing practices: doing market research, choice of location, setting a price, negotiating with suppliers, using advertising, evaluating advertising, and creating a brand. The training lasted for two full workdays, from 8 a.m. to 6 p.m. each day, for an approximate total of 20 hours per cohort.

The training program was taught by two instructors, who were local consultants. Two new groups of entrepreneurs started each week, one on Monday and one on Wednesday. The instructors taught the classes together, following a strict schedule. There were catered coffee and lunch breaks each day. The program also included a networking event at the end of the two days. During this networking event, after all the teaching material had been covered, participants were randomly assigned three discussion partners from within the same class. Participants were then given space for private one-on-one conversations with each of their discussion partners. These conversations lasted approximately 30-45 minutes each. During the conversations, participants were given writing materials to take notes on their conversations.

\section{Experimental Treatment}

To test whether improving communication practices shapes entrepreneurs' interactions, business relationships, and profitability, we randomly assigned cohorts of entrepreneurs in the Marketing in Action program into two conditions, a "communication practices" condition and a control condition. Participants in the treatment condition began the two-day training program with a two- 
hour training session on communication practices. Prior field experimental research has used such training sessions and lectures as effective interventions for changing practices and shared understandings in organizational settings (e.g., Cable et al. (2013) and Paluck (2011)). After the communication practices session, the treatment groups followed a series of interactive lectures during the remaining two days that covered the marketing practices. The control group followed the exact same training program, except that they were not given the two-hour lecture on communication practices. Instead, the lectures on marketing practices were covered at a slightly slower pace to make up for the two hours that the treatment group spent on communication practices. $^{3}$ As a result, both control and treatment groups spent exactly the same number of hours together.

Our treatment, the two-hour training session, introduced entrepreneurs to the three communication practices outlined in the theory section: asking questions and giving advice, reflecting on others, and following up. Table 1 provides an overview of the structure of the session. During the first hour, the first 20 minutes were spent teaching how advice-giving involves a process of learning about others by asking them questions about their businesses and translating one's own experiences into advice that others can understand (Argyris, 1991). Entrepreneurs were also taught that giving advice also created the possibility of receiving useful information from others in return. Then, after the discussion on the practice of asking questions and giving advice, another 20 minutes were spent on the practice of reflecting on others. This component focused on how a social setting can be an opportunity to meet and learn from someone new, which involves noticing who else is in a given social setting and whether they might contribute to achieving one's own goals (Cross and Thomas, 2011; Edmondson, 2012) . Finally, in the next 20 minutes, entrepreneurs were walked through how to follow up after initial interactions. This involved simple steps like making sure to ask for contact information, sending thank-you notes, and talking about business issues that could be followed up on in the future. To

\footnotetext{
${ }^{3}$ In order to introduce the two-hour training session into the program, we chose to condense the amount of time spent on marketing practices rather than add an additional two hours for the treatment condition because this would have represented an approximate increase of $10 \%$ in the total time that entrepreneurs in that condition spent together. We chose to avoid this increase in total time spent together because it could have confounded the effects of the communication intervention on our outcomes of interest related to communication and relationship formation. Notably, test scores for comprehension of the marketing practices showed no difference between the control and communication practices conditions.
} 
reinforce the entrepreneurs' understanding of the three communication practices, the final hour of the training session was spent working through a brief case study about communication, using a fictional example of a Togolese entrepreneur. This was followed by time for questions and answers.

*** Insert Table 1 about here ***

The instructors who led the session on communication practices also taught the other materials in the two-day training program, which helped with the integration of the session into the rest of the program. The two instructors co-taught all materials; as a result, they were both present in all classes. As well as being consultants, the instructors were graduates of the local university who each had several years of experience teaching courses to entrepreneurs. One of the authors trained the two instructors on communication practices and walked them through the content of the lecture. Before the start of the training programs, the instructors practiced and refined giving the presentation. Although the instructors were trained in communication practices, they were blind to the design of the field experiment and the authors' outcomes of interest. The PowerPoint slides developed with the instructors for this session can be found in Appendix I.

\section{Data}

The data for this study come from five sources: (1) pre-treatment survey; (2) digitized participant notes; (3) training program exit survey; (4) six-weeks post-treatment survey; and (5) six-months post-treatment survey. The pre-treatment survey and the two post-treatment surveys (sources 1, 4, and 5) collected information from all participant entrepreneurs about their management practices, networking practices, expenditures, revenues, employees, and other demographic information. The two follow-up surveys conducted after the training program (sources 4 and 5) contained additional questions on participants' contact with other participants from their class in the training program; these were used to measure relationship formation. The digitized participant notes (source 2) are handwritten notes that participants took of their discussions with other participants during a structured networking event, which were electronically scanned. The exit survey (source 3), asked all participants questions about their interactions during the two days of the program and their perceptions of other participants, as well as their comprehension of 
the material taught. The survey questions used to construct the variables for our analyses can be found in Appendix J.

All surveys were administered by the same two instructors who taught the training program. During registration for the program, the instructors explained to the entrepreneurs about the follow-up survey process and that they themselves would be visiting the participants later to survey them. This helped build a sense of commitment and trust between the instructors and the participants.

Although 326 entrepreneurs signed up to participate in the training program, 10 did not finish their training. Five entrepreneurs were unable to attend the second day of the training due to unforeseen circumstances, such as a health condition or business emergency. During the followup surveys, 15 more entrepreneurs fell out of the sample, leaving a total of 301 participants. Most of the entrepreneurs who dropped out at this stage were either away from Lomé for prolonged periods of time for travel or had had to stay away from their work due to health issues, such as malaria. ${ }^{4}$

\section{Dependent Variables}

Cooperative perception of interactions. Our first hypothesis (H1a) is that entrepreneurs will perceive interactions during the training program as more cooperative than competitive after they have been exposed to communication practices. To measure entrepreneurs' perception of interactions, we asked them to think about the interactions they had had during the two days of the training program. We then provided them with a sheet of paper with a grid of 24 words, of which half represented concepts related to collaboration (such as help, trust) and the other half represented concepts related to competition (such as grow, dominate), and asked them to circle five words that they believed best represented these interactions. ${ }^{5}$ Using this information, we

\footnotetext{
${ }^{4}$ To further check that attrition did not bias the randomization of the treatment, we ran an OLS regression for receiving treatment ( 1 if in the treatment group, 0 otherwise) as a function of attrition (a binary indicator for not having completed the training program or the two follow-up surveys). In this regression, the coefficient of attrition was insignificant (Coef 0.148; St. Err. 0.126), indicating that attrition did not impact treatment.

${ }^{5}$ Other cooperative words included friendship, sharing, and alliance, while other competitive words included adversarial, beat, and dominate. For the full list of words, see Appendix J.
} 
created a measure of cooperative perception of interactions for each entrepreneur, which was a count variable equal to the total number of cooperative words selected from the grid of 24 words.

Information exchange. The second hypothesis (H1b) states that entrepreneurs will exchange more information after they've been exposed to communication practices. To measure information exchange between entrepreneurs, we created a structured networking event at the end of the training program, during which each entrepreneur was successively paired with three randomly selected discussion partners. All participants were given pen and paper, and at the end of the event, their written notes from their discussions were scanned. The total number of words that each participant wrote during their three discussions was used as a measure of information exchange (Aral and Van Alstyne, 2011).

Relationship formation. The third outcome of interest is how many relationships an entrepreneur formed with other participants in the training class (H2a). To measure relationship formation, we used data from the follow-up survey conducted six weeks after the training program. During the follow-up survey, all participants were asked whether they had spoken over the phone or met in person with any other participants from the same training group after the program had ended, and they were asked to name those individuals. This post-training contact was taken as an indication of a relationship having been formed between two participants. Using these data, we calculated the number of relationships formed for individual participants as the number of people they had kept in touch with (Vissa, 2011; Piezunka and Dahlander, 2019).

Skill complementarity. Hypothesis $\mathrm{H} 2 \mathrm{~b}$ relates to the proportion of relationships formed with entrepreneurs who possess complementary business skills. The measure for skill complementarity is adapted from the dyad-level measure used by Vissa (2011) for task complementarity and captures whether the focal entrepreneur formed a relationship with another training-class participant who has a skill that the focal entrepreneur has expressed a desire to learn.

To construct this measure, we use survey responses in which participants were asked to describe one issue in their business that they felt was the most pressing and that they wished to address. 
They were asked to select which category this specific issue fell into: (1) firm financing; (2) marketing; (3) stock and inventory management; (4) accounting and record keeping; (5) planning for the future. We used the list of business best practices (which cover all five areas of expertise) developed by the World Bank (McKenzie and Woodruff, 2018). In parallel, based on their responses to the pre-treatment survey, we coded each participant according to whether they used best practices in those five categories.

Using these two data points (i.e., the skill that each participant most desired to learn and each participant's portfolio of skills), we created an indicator of skill complementarity between each pair of participants $i$ and $j$ which was equal to 1 if participant $j$ showed evidence of expertise in best practices in the domain in which participant $i$ indicated a wish to improve. Then, to bring this measure from the dyadic level to the individual level, we calculated the proportion of relationships with skill complementarity by taking the ratio of relationships characterized by skill complementarity to the total number of relationships formed after the training program. This measure ranged from 0 to 1 , where 0 means that none of the connections formed exhibit skill complementarity and 1 means that all connections formed exhibit skill complementarity.

Ethnic concentration. Hypothesis $\mathrm{H} 2 \mathrm{c}$ states that better communication practices will lead to the formation of more diverse relationships. Ethnic concentration of relationships represents the level of concentration of the newly formed relationships across ethnic groups. Using the pretreatment data regarding each entrepreneur's ethnicity, we calculated the ethnic concentration of the relationships formed using Herfindahl indexes, a common approach for measuring diversity in egocentric portfolios of relationships (Uzzi, 1996). The index ranges between a minimum of $1 / \mathrm{N}$, where $\mathrm{N}$ is the number of possible categories represented in the sample, and 1 . The minimum value indicates that all relationships were equally distributed among the ethnicities, and the maximum value (" 1 ") indicates that all relationships formed were concentrated in one ethnicity or one neighborhood. In the case of ethnicities, there are five possible cases, making the minimum value of the index 0.20 .

Performance. Finally, Hypothesis 3 is about the performance of entrepreneurs' businesses. The measure for business performance comes from three surveys: a pre-treatment survey at the 
beginning of the training and two post-treatment surveys at six weeks and six months after the training. In each survey, we asked participants about their businesses' profits in the month previous to the interview. Self-reported monthly profits is a standard measure of performance for small businesses in developing economies, which is highly correlated with other measures of performance based on accounting books (De Mel, McKenzie, and Woodruff, 2009; Atkin, Khandelwal, and Osman, 2017).

\section{Independent Variable}

Treatment group. The main independent variable in the analyses is whether the individual participated in a group that received the communication practices treatment. Accordingly, we created a dummy variable equal to 1 for having received the treatment, and 0 for being in the control group.

\section{Control Variables}

Although the research design randomizes the exposure to communication practices, we also accounted for variation in the characteristics of entrepreneurs and their businesses in the regression models. Specifically, we included as control variables several conventional factors that may be related to perceptions of interactions, information exchange, relationships formed, and performance.

First, we controlled for Ewe ethnicity, coded as 1 if the participant was Ewe (the majority ethnic group in Lomé) and 0 otherwise. This was measured in the first post-treatment survey by asking participants what language they spoke at home, which is a common indicator of individuals' ethnic group (Yenkey, 2015). Being a member of the majority group could increase the number of potential interaction partners during the training program, thereby making it easier to form more relationships. In addition to ethnicity, we controlled for entrepreneurs' gender by including an indicator for female entrepreneurs. Cultural beliefs about gender and entrepreneurship can make it more difficult for women entrepreneurs to form new relationships (Field, Jayachandran, and Pande, 2010); therefore, we controlled for this factor. We also controlled for whether participants had completed primary school, which was coded as 1 if the participant had completed at least primary school and 0 otherwise. Completion of primary school is a way of 
gauging whether the participant was functionally literate. Entrepreneurs with less than a primary school education are unlikely to have facility with reading and writing, which is also an indicator of lower socioeconomic status in Togolese society.

Furthermore, three control variables were included to capture various aspects of participants' businesses. First, we controlled for the size and age of the participant's business using the number of employees, measured by the log of total number of full-time employees working in the business, and firm age, measured by the number of years since the business started producing and selling goods or services. These factors may affect relationship formation because entrepreneurs with larger and more established businesses tend to be higher-status and therefore perceive fewer participants as attractive interaction partners (Ruef, Aldrich, and Carter, 2003).

We also controlled for the extent to which each participant used established best practices for management in their businesses. Using the management practices score for small businesses in developing economies created by McKenzie and Woodruff (2018), we collected data in the pretreatment survey through a series of "yes or no" questions about whether participants used each of the best practices in a list of 27 practices. ${ }^{6}$ The management practices score of a participant's business is the proportion of the 27 questions to which the entrepreneur answered "yes." We controlled for this because participants with higher scores may be less motivated to interact, communicate, or create new relationships.

Furthermore, a series of 10 dummy variables was created to capture entrepreneurs' sector of economic activity. The 10 sectors were tailoring and shoemaking, sale of food or drink, jewelrymaking and sales, information technology sales and services, cosmetic and health services, construction, food processing and production, carpentry and metal works, rug manufacturing and weaving, and multimedia services.

Finally, we controlled for the training class size, which is equal to the number of entrepreneurs in each training program class. This was included to control for the number of prospective

\footnotetext{
${ }^{6}$ These best practices include, for example, recording every purchase and sale, using advertising, and having a monthly budget of expenses. See McKenzie and Woodruff (2018) for a complete list and details.
} 
connections each actor had available, which could have a positive effect on the total number of relationships formed, but a negative effect on the level of familiarity with those individuals.

We report the summary statistics and bivariate correlations in Table 2 . The majority of participants (78 percent) were members of the Ewe ethnic group and had completed primary school (75 percent). Approximately 66 percent of entrepreneurs were male. Entrepreneurs' businesses had on average one or two employees and had been in existence for 11 years. In general, larger businesses tended to be more profitable. Finally, in terms of best practices, entrepreneurs' businesses on average used about 60 percent of the practices defined by the World Bank for small businesses. The higher use of best practices was positively associated with firm size and age. In Appendix B, we report balance tests, which explore whether baseline characteristics predict being in the treatment group. We find no statistically significant evidence that any baseline characteristics of the entrepreneurs or their businesses predicts receiving the treatment.

** Table 2 about here **

\section{Estimation}

Our estimation strategy builds on a pre-registration plan, ${ }^{7}$ but better takes into account the kinds of outcome variables and their longitudinal structure. Among the dependent variables, there are three kinds: count, fractions, and normally distributed. All dependent variables are crosssectional, except for the performance dependent variable, logged profits last month, which is a panel time series with three periods.

\footnotetext{
${ }^{7}$ We pre-registered our field experimental design and our expected outcomes with the Open Science Foundation (OSF) at https://osf.io/qpydj/. Our pre-registration document refers to communication practices as "cultural frames of cooperation and helping" and explicitly outlines our first three hypotheses. The OSF included one predictionthat the treatment should increase "relational knowledge" - for which we did not end up collecting data to test. We did not register our final two hypotheses. We did not initially think we could measure firm performance but ended up having funds for surveys after the program. For ethnic diversity, we did not realize that the prediction followed from our model until discussing our findings with colleagues. Our pre-registered analyses use OLS and hold as shown in Appendix E.
} 
The first group of dependent variables comprises cooperative perception of interaction (H1a), information exchange (H1b), and relationships formed (H2a), which are count variables. To test hypotheses H1a, H1b, and H2a, we used a negative binomial model, which is appropriate for models where the dependent variable is a count with nonnegative values (Cameron and Trivedi, 2009).

The dependent variables skill complementarity $(\mathrm{H} 2 \mathrm{~b})$ and ethnic concentration $(\mathrm{H} 2 \mathrm{c})$ are ratios, which range from at most 0 to 1 . To test hypotheses $\mathrm{H} 2 \mathrm{~b}$ and $\mathrm{H} 2 \mathrm{c}$, we used fractional logit regressions, which is appropriate for models where the dependent variable is a fraction (Papke and Wooldridge, 2008). Finally, the dependent variable for performance (H3) is logged monthly profit. We log the variable because profits, as is regularly the case, is highly skewed. We use ordinary least squares (OLS). We included sector dummies to account for unobserved heterogeneity across sectors of activity and clustered standard errors by training groups (i.e., we let observations be independent across groups but not necessarily across the participants of the same group) in all models.

\section{RESULTS}

\section{Cooperative Perception of Interactions and Information Exchange}

Hypothesis 1a posits that entrepreneurs who have been exposed to communication practices will perceive interactions with other entrepreneurs as more cooperative. Table 3 presents regression results that test this hypothesis. All regressions in Table 3 are estimated using a negative binomial model because the outcomes are count variables, with standard errors that are clustered at the classroom level. In addition to the controls shown, each model also contains fixed effects for entrepreneurs' sector of activity and a constant, which are not shown in the table. In Models 1 and 2, the dependent variable is the number of cooperative words that entrepreneurs selected to describe their interactions during the training program. Model 1 presents the set of control variables, of which only the class size has a statistically significant effect on number of cooperative words selected, though the magnitude is small. Model 2 introduces the variable for the treatment, communication practices. The coefficient for this variable is positive and 
statistically significant at the 5-percent level. Using predictive margins and keeping all other variables at their means, being in the treatment group leads to selecting 0.25 more cooperative words, an increase equivalent to roughly one-quarter of a standard deviation. These results provide empirical support for Hypothesis 1a that entrepreneurs who were exposed to communication practices did perceive interactions as more cooperative.

Hypothesis $1 \mathrm{~b}$ states that entrepreneurs exposed to communication practices will exchange more information during interactions with other entrepreneurs. To measure information exchange during interactions, we counted the number of words written during three discussions that each entrepreneurs participated in during the structured networking event at the end of the second day of the training program. Figure 1 shows the plots of the kernel density function for the number of words written during the three discussions by participants in the treatment and control groups. The red dashed line is the distribution for participants in the treatment condition, while the solid blue line represents those in the control group. Figure 1 shows that the distribution for the treatment group is shifted significantly to the right of the distribution of the control group. Models 3 and 4 of Table 3 test this hypothesis using regressions and controlling for entrepreneur and business characteristics. Model 3 presents only control variables. Model 4 introduces the treatment variable, which is positive and statistically significant at the 1 percent level. The predictive margins show that being in the treatment group increases the average number of words written by 27, which represents a doubling of the number of words written. These results lend support to Hypothesis $1 \mathrm{~b}$ that entrepreneurs who were exposed to communication practices exchanged more information during interactions.

\author{
*** Insert Figure 1 about here *** \\ *** Insert Table 3 about here $* * *$
}

\title{
Relationship Formation
}

Hypothesis 2a states that exposure to communication practices will lead to the formation of more new relationships between entrepreneurs. Figure 2 shows the plots of the kernel density functions for the number of new relationships formed, as measured six weeks after the end of the training 
program, for the treatment and control groups. The figure shows that the distribution for the treatment group is shifted to the right of the distribution for the control group, indicating that there is a higher frequency of larger numbers of relationships formed. The regressions in Table 4 confirm this difference between the two groups. Specifically, Models 1 and 2 of Table 4 estimate the effect of communication practices on the number of new relationships formed after the training program. Model 1 of Table 4 presents the control variables, of which only being a member of the Ewe ethnicity is statistically significant at the 5 percent level. Given that this is the majority ethnic group, being a member of it increases the ease of forming new relationships for entrepreneurs. Model 2 introduces the treatment variable, which is positive and statistically significant. In order to assess the substantive significance of the results, we calculated the predicted count of ties for participants in the control and treatment groups, while keeping the other covariates at their means. The predicted count of ties for participants in the control group is 1.5, compared with 2.25 in the treatment group. Given that the median participant in the control group formed approximately two ties, the addition of (about) one more tie through the treatment represents a large increase in the outcomes from the treatment. Therefore, the results provide strong support to the prediction that entrepreneurs that have been exposed to communication practices will form more relationships with other entrepreneurs.

*** Insert Figure 2 about here ***

\section{Skill Complementarity}

We further hypothesized that entrepreneurs exposed to communication skills would form a greater proportion of relationships that exhibit skill complementarity (Hypothesis 2b). In line with this hypothesis, the proportion of relationships that exhibit skill complementarity (i.e., those in which the target possesses a skill that the focal entrepreneur has expressed the wish to improve upon) were on average higher for individuals in the treatment group than those in the control group. The regression analyses support Hypothesis $2 \mathrm{~b}$ as well: the coefficient for exposure to communication skills is positive and statistically significant at the 5 percent level on the proportion of ties exhibiting skill complementarity in Model 4 of Table 4. Based on the predictive margins for this model, receiving the treatment increases the proportion of the entrepreneur's network that is task complementary by about 15 percent, when keeping other 
covariates constant at their means. Taken together, these results provide support for Hypothesis $2 b$.

\section{Ethnic Diversity}

Hypothesis 2c stated that communication practices will lead to the formation of more ethnically diverse relationships. This is tested using a measure of the concentration of new relationships formed within ethnic groups. Because this measure ranges from 0 to 1, Models 5 and 6 in Table 4 use a fractional logit model. In Model 5, the only statistically significant control variables are having completed primary school, which lowers the ethnic concentration of new ties, and the number of employees, which increases the concentration. Model 6 introduces the variable for the treatment, whose coefficient is negative and statistically significant at the 1 percent level, indicating that being in the treatment group decreases the ethnic concentration of new relationships formed. The effect is meaningful, with the marginal effect being -0.11 , which is nearly half of a standard deviation. This result provides support for Hypothesis $2 \mathrm{c} .^{8}$

*** Insert Table 4 about here ***

\section{Business Performance}

The final hypothesis posited that communication practices will lead to better performance for entrepreneurs. In particular, it was theorized that exposure to communication practices will lead to an increase in monthly profits, measured six months after the training program. Figure 3 plots the kernel density function of the logged profits for the treatment and control groups. The red dashed line represents the treatment group, and it is shifted to the right of the blue solid line that represents the control group. This indicates that at every level of the distribution of business performance, entrepreneurs experienced increases. As shown in Appendix $\mathrm{C}$, the visual shift in distributions is comparable to past work testing the effects of peer groups on firm performance (Cai and Szeidl, 2017).

\footnotetext{
${ }^{8}$ In addition to ethnic diversity, gender diversity is also an important dimension of entrepreneurs' portfolios of relationships. However, after conducting exploratory analyses, we find no effects of the treatment on the gender composition of entrepreneurs' peer relationships. For these analyses, see Appendix H.
} 
To test the significance and magnitude of this effect, we use a difference-in-differences type approach. Table 5 shows the results for OLS regressions for logged monthly profit before, six weeks after, and six months after the program. Model 1 shows the results without entrepreneur fixed effects, while Model 2 includes entrepreneur fixed effects. The effect of communication practices is significant at the 5 percent level in both models. The coefficient estimates indicate that communication practices in the post-treatment period were associated with an approximately 50 percent increase in monthly profits, roughly one-quarter of a standard deviation.

Why do we observe such a large percentage change? In our data, the baseline monthly profits and sales are quite low. For example, the median firm in our sample has revenues of 768 USD per month and a profit of 168 USD per month. As a result, small improvements, such as gaining a new client, selling several more units, or finding a better supplier, can lead to very large percentage increases in profits. It is not uncommon for interventions with small-scale entrepreneurs in developing economies to have the effect of increasing profits by 100 percent (e.g., see McKenzie and Sakho 2010). One recent field experiment testing the effect of a training program on entrepreneurs in Tanzania found that their intervention led to increases in profits of about 50 percent (Berge, Bjorvatn, and Tungodden, 2014), which is a similar effect size to ours in Table 5. Furthermore, consistent with prior work, in Model 1 of Table 5, we find a strong association between management practices and number of employees and the firm's profitability. This increases our confidence that our measure of profits is not merely noise.

The results of these analyses are consistent with the theory and confirm Hypothesis 3 . Additional details on the interpretation of the kernel density functions for performance and a comparison of the magnitude of the treatment effect with those in other studies can be found in Appendix C.

*** Insert Figure 3 about here $* * *$

*** Insert Table 5 about here ***

\section{ROBUSTNESS CHECKS}


We also conducted a series of robustness checks to validate these results. First, to confirm that the measure of new business relationship formation accurately captures the effect of communication practices on the number of new relationships formed, we estimated the models using an alternative outcome variable. Specifically, we adapted a measure from Vissa (2011), who uses the receipt of a business card to measure intention to form a relationship. To create this measure, we provided all entrepreneurs with personalized business cards with their name and phone number printed on them, and we told them they could use them as they wished. At the end of the two days, we asked the participants to show us the cards they had received from others and we took note of each card received. Following the same model specification as in Table 3, but changing the outcome variable to be the number of cards received, we replicated the result for number of relationships formed from Table 3. This helps verify that our outcome measure was accurately capturing the dynamics that better communication practices lead to more new relationships. For details on these results see Appendix G.

An additional concern may relate to the skill complementarity results. Perhaps entrepreneurs were not seeking out others with the skills they needed, but rather by simply making more relationships, they accidentally ended up with more good matches. In other words, perhaps the increased skill complementarity is an accidental by-product of building more relationships. To confirm that the observed differences in skill complementarity were not simply the result of network growth, we ran a series of simulations where the number of new relationships that each entrepreneur formed was held at the observed value, but the targets of those relationships were randomly selected. Then the proportion of skill-complementary relationships was calculated for the treatment and control. This was repeated for 2,000 simulations. In Appendix D, we plot the simulated differences. The actual difference between skill complementarity in the treatment and control groups is extremely unlikely to happen by chance (less than one-tenth of a percent). Forming more ties does not necessarily result in more useful connections.

Furthermore, an additional potential concern may relate to the model dependence of our results. The regressions in Tables 3 and 4 estimate non-linear models. As a precaution, we estimated all regressions in these tables using OLS. This has the added benefit of making the interpretation of the results simpler as well. All of our results held unchanged using this regression approach, as 
did the interpretation of the magnitudes of the effects. For details on these robustness checks, see Appendix E.

Finally, we re-estimate all models including additional controls for gender, being formally registered, having received a loan, and networking practices, inserting them one by one and in combinations. The inclusion of these variables, none of which were significant, did not change the results.

\section{DISCUSSION AND CONCLUSIONS}

Existing research has long argued that having a large and diverse portfolio of peer advice relationships has significant benefits for entrepreneurs' survival, growth, and business performance (Aldrich and Zimmer, 1986; Stuart and Sorenson, 2007). Peers can supply information about market opportunities and advice about business practices (Renzulli, Aldrich, and Moody, 2000; Kuhn and Galloway, 2015). This study explores the role of communication practices in interactions with peers, the formation of new relationships, and business

performance. Using a field experiment in Togo, this study provides causal evidence that simple communication practices enable entrepreneurs to make more out of social opportunities to interact by making interactions more cooperative, increasing information exchange, and leading to the formation of new relationships. The peer relationships formed due to such communication practices are not only more useful in terms of access to complementary skills, but also more ethnically diverse. Beyond affecting the formation of new business relationships, communication skills are also associated with improvements in business performance.

\section{Contributions}

First, our study contributes to the foundational literature on inter- and intra-organizational communication. Classical organization theory has long studied the various formalized structures and practices, including scripts, codes, and shared cultures, that are necessary to facilitate effective communication and information flows within organizations (Tushman, 1978; Kogut and Zander, 1996; Weber and Camerer, 2003; Srivastava et al., 2017; Choudhury et al., 2019). Research has also examined the factors that enable inter-organizational communication as it 
relates to learning and knowledge transfer, emphasizing factors such as absorptive capacity and "knowledge gatekeepers" (Tushman and Katz, 1980; Cohen and Levinthal, 1990). While these studies have considerably enriched our understanding of communication within and between organizations, they remain silent about the role of communication practices, especially in entrepreneurial settings. We address this gap by identifying three simple communication practices for entrepreneurs and providing experimental evidence of their effects. The results are compelling in that they affect not only entrepreneurs' ability to exchange information, they also change the composition of their peer relationships and improve their performance. These results also highlight that communication can be theorized as a bundle of practices, which may have significant implications for how organizations pursue the development of better communication flows (O'Reilly III and Roberts, 1974).

In addition to this, our study also contributes to the literature on entrepreneurship and the formation of peer business relationships. Existing research has focused primarily on the structural characteristics of dyads to explain the formation of business relationships (Rivera, Soderstrom, and Uzzi, 2010). This work has identified factors such as homophily (Abraham, 2019), proximity (Hallen, 2008; Dahlander and McFarland, 2013; Hasan and Bagde, 2015), mutual ties (McFarland et al., 2014), and common organizational membership (Feld, 1981) as significant predictors for the formation of peer business relationships. We build on this literature by examining a non-structural factor related to relationship formation: communication. This study shows that entrepreneurs' exposure to communication practices affects the way they perceive interactions and the information that is exchanged during those interactions, thereby increasing and diversifying the number of relationships they form. Given that prior work has found that structural factors, such as homophily, that lead to relationship formation often reproduce existing social relationships and divisions (Ingram and Morris, 2007), we think that the results of this study are especially crucial, as they offer evidence of an intervention that promotes the formation of new and diverse ties, thereby potentially changing social hierarchies.

Finally, this study contributes to the study of entrepreneurship in developing countries. Existing research on entrepreneurs in developing markets has emphasized the importance of management practices (Bloom et al., 2013; McKenzie and Woodruff, 2018). Some researchers have also 
begun to note the importance of relationships for entrepreneurs in developing markets (Acquaah, 2012; George et al., 2016a; Armanios et al., 2017). However, these studies are limited in their ability to shed light on the dynamics involved in the formation of relationships in these contexts. In particular, these studies do not provide any guidance as to how entrepreneurs can overcome obstacles to forming relationships with other entrepreneurs. This study helps fill that gap by showing that communication practices can help entrepreneurs form relationships within specific settings, thus overcoming many barriers to relationship formation that are endemic to developing markets.

Beyond its contributions to various theoretical literatures, this study also makes a methodological contribution to the study of entrepreneurship and organizations. In this study, we leveraged field experimental methods, which are still nascent in the field of organization theory research (notable exceptions include Bernstein (2012) and Ranganathan (2018)). One benefit of this approach is that it allows us to make causal evaluations of the relationship between communication practices, information exchange, and relationship formation. To achieve this, we designed an experimental setup with well-defined treatment and control groups. A second benefit of this methodological approach is that it enabled us to measure elements of information exchange and patterns of interactions at a more fine-grained level than most other studies of business relationship formation have so far been able to. Our hope is that future studies will continue to build and add to the repertoire of this methodology.

\section{Boundary Conditions and Future Research Directions}

An important aspect of this study is that it was conducted in Togo, which was a compelling setting for testing our theory, but it also represents a boundary condition. Togo offered a context in which many entrepreneurs were active but also faced difficulties in communication with peers. As a result, this setting enabled us to observe and measure the effect of communication practices. Yet Togo is also a low-income country with weak formal market institutions, where entrepreneurs face high levels of uncertainty and risk in markets (Marquis and Raynard, 2015). As a result, it is possible that in settings where communication is easier due to prevailing norms, institutions, and the social infrastructure, an intervention that involves exposing entrepreneurs to communication practices may not have as large or as measurable effects. If this is true, 
discussing communication practices with entrepreneurs may be less important in highly developed institutional environments. Nevertheless, uncertainty is at the basis of much entrepreneurial activity (Alvarez and Barney, 2005), and therefore there is a good chance that in many environments improving communication practices will have an effect.

Second, in the design for this study, the exposure to communication practices was brief and the opportunities for interactions were constrained to the two days that the training program lasted. Although the treatment was limited, results did show statistically significant changes in patterns of interaction and performance. Nevertheless, it is unclear whether a longer and more thorough exposure to the communication practices would alter the results. It is possible that actors would create more ties and that these ties would be more durable over time. This, in turn, could increase their performance even more. Furthermore, there is also a possibility that creating more connections could lead to negative social capital, whereby successful entrepreneurs are burdened by the connections and the favors that are asked of them. Future studies should explore these dynamics with more comprehensive treatment designs.

Third, the exposure to communication practices took place within the context of a business training program, and the treatment was administered to entire groups at the same time. It is unclear how the results of this intervention would have changed if the exposure to communication practices had happened to randomly selected individuals before they joined the training program. It is possible that the size of the effect may be diminished when training groups contain a mix of entrepreneurs who have been shown communication practices and entrepreneurs who have not. We are unable to determine the extent to which the treatment relies on the presence of a group norm, in addition to entrepreneurs being familiar with the practices. We believe that this represents an opportunity for future research on how communication practices depend on the structure and the norms of the spaces within which they are deployed.

Finally, this study examined the specific case of entrepreneurs. Entrepreneurs have a strong incentive to create new ties and search for new information. As a result, it is possible that the treatment was very appropriate for entrepreneurs, but might be less so for other types of actors. For example, would communication practices resonate with corporate executives? In theory, in 
any setting in which actors have the potential to mutually help each other, communication should lead to the formation of new relationships that increase performance. Moreover, scholars have emphasized the need for effective communication in large organizations and teams (Edmondson and Lei, 2014). However, due to the emphasis of this study on entrepreneurs, it remains to be tested whether this dynamic replicates for other types of market actors and whether there are differences in the effects.

\section{Conclusion}

Entrepreneurs depend on peer relationships for access to information, especially in the context of developing countries. Forming business relationships with individuals who provide access to useful information is difficult. Although there is considerable research on the macro structures that can play a role in the formation of these types of ties, this study introduces an additional mechanism of communication. We argue that when exposed to communication practices, entrepreneurs perceive interactions more cooperatively and exchange more information during those interactions. In turn, this enables entrepreneurs to form more business relationships, of which a larger proportion exhibit skill complementarity and are more ethnically diverse. Finally, communication practices are also associated with better performance subsequently. Analyses of data from a field experiment in Togo provide supportive evidence for these claims.

Communication practices appear to be a promising tool to catalyze the formation of relationships between entrepreneurs even within some of the most challenging environments. 


\section{REFERENCES}

Abraham, M.

2019 "Gender-role Incongruity and Audience-based Gender Bias: An Examination of Networking among Entrepreneurs." Administrative Science Quarterly.

Acquaah, M.

2012 "Social networking relationships, firm-specific managerial experience and firm performance in a transition economy: A comparative analysis of family owned and nonfamily firms." Strategic Management Journal, 33: 1215-1228.

Acs, Z. J., S. Desai, and J. Hessels 2008 "Entrepreneurship, economic development and institutions." Small Business Economics, 31: 219-234.

Aldrich, H. E. and P. H. Kim 2007 "Small worlds, infinite possibilities? How social networks affect entrepreneurial team formation and search." Strategic Entrepreneurship Journal, 1: 147-165.

Aldrich, H. E. and C. Zimmer 1986 "Entrepreneurship through social networks." In D. Sexton and R. Smilor (eds.), The art and science of entrepreneurship: 3-23. Cambridge, MA: Ballinger.

Allen, T. J.

1966 "Performance of information channels in the transfer of technology." Industrial Management Review, 8: 87.

Allen, T. J. 1984 Managing the Flow of Technology: Technology Transfer and the Dissemination of Technological Information within the R\&D Organization. Cambridge, MA: MIT Press.

Allen, T. J. and S. I. Cohen 1969 "Information flow in two R\&D laboratories." Administrative Science Quarterly, 14: 12-19.

Alvarez, S. A. and J. B. Barney 2005 "How do entrepreneurs organize firms under conditions of uncertainty?" Journal of Management, 31: 776-793.

Aral, S. and M. Van Alstyne 2011 "The diversity-bandwidth trade-off." American Journal of Sociology, 117: 90-171. Argyris, C.

1991 "Teaching smart people how to learn." Harvard Business Review, 69: 99-109.

Armanios, D. E., C. E. Eesley, J. Li, and K. M. Eisenhardt 2017 "How entrepreneurs leverage institutional intermediaries in emerging economies to acquire public resources." Strategic Management Journal, 38: 1373-1390.

Assenova, V. A. and O. Sorenson 2017 "Legitimacy and the benefits of firm formalization." Organization Science, 28: 804818.

Atkin, D., A. K. Khandelwal, and A. Osman 2017 "Exporting and firm performance: Evidence from a randomized experiment." Quarterly Journal of Economics, 132: 551-615.

Azoulay, P., C. C. Liu, and T. E. Stuart 2017 "Social influence given (partially) deliberate matching: Career imprints in the creation of academic entrepreneurs." American Journal of Sociology, 122: 1223-1271. 
Baldassarri, D.

2015 "Cooperative networks: Altruism, group solidarity, reciprocity, and sanctioning in Ugandan producer organizations." American Journal of Sociology, 121: 355-395.

Berge, L. I. O., K. Bjorvatn, and B. Tungodden

2014 "Human and financial capital for microenterprise development: Evidence from a field and lab experiment." Management Science, 61: 707-722.

Bernstein, E. S.

2012 "The transparency paradox: A role for privacy in organizational learning and operational control." Administrative Science Quarterly, 57: 181-216.

Bloom, N., B. Eifert, A. Mahajan, D. McKenzie, and J. Roberts 2013 "Does management matter? Evidence from India." Quarterly Journal of Economics, 128: $1-51$.

Brooks, A. W. and L. K. John 2018 "The surprising power of questions." Harvard Business Review, 96: 60-67.

Burt, R. S.

1992 Structural Holes: The social Structure of Competition. Cambridge, MA: Harvard University Press.

Burt, R. S. and D. Ronchi

2007 "Teaching executives to see social capital: Results from a field experiment." Social Science Research, 36: 1156-1183.

Cable, D. M., F. Gino, and B. R. Staats

2013 "Breaking them in or eliciting their best? Reframing socialization around newcomers' authentic self-expression." Administrative Science Quarterly, 58: 1-36.

Cai, J. and A. Szeidl 2017 "Interfirm relationships and business performance." Quarterly Journal of Economics, 133: 1229-1282.

Cameron, A. C. and P. K. Trivedi 2009 "Microeconometrics with STATA." College Station, TX: StataCorp LP.

Carrell, S. E., B. I. Sacerdote, and J. E. West 2013 "From natural variation to optimal policy? The importance of endogenous peer group formation." Econometrica, 81: 855-882.

Casciaro, T., F. Gino, and M. Kouchaki 2016 "Learn to love networking." Harvard Business Review, 94: 104-107.

Casciaro, T. and M. S. Lobo 2005 "Competent jerks, lovable fools, and the formation of social networks." Harvard Business Review, 83: 92-99.

Chatterji, A., S. Delecourt, S. Hasan, and R. M. Koning 2018 "When Does Advice Impact Startup Performance?" Strategic Management Journal, 40: 331-356.

Choudhury, P., D. Wang, N. A. Carlson, and T. Khanna 2019 "Machine learning approaches to facial and text analysis: Discovering CEO oral communication styles." Strategic Management Journal.

Cohen, W. M. and D. A. Levinthal 1990 "Absorptive capacity: A new perspective on learning and innovation." Administrative Science Quarterly, 35: 128-152.

Collins, R. 
2004 Interaction Ritual Chains. Princeton, NJ: Princeton University Press.

Cross, R., A. Parker, L. Prusak, and S. P. Borgatti

2001 "Knowing what we know: Supporting knowledge creation and sharing in social networks." Organizational Dynamics, 30: 100-120.

Cross, R. and R. Thomas 2011 "A smarter way to network." Harvard Business Review, 89: 149-153.

Dahlander, L. and D. A. McFarland 2013 "Ties that last: Tie formation and persistence in research collaborations over time." Administrative Science Quarterly, 58: 69-110.

De Mel, S., D. J. McKenzie, and C. Woodruff 2009 "Measuring microenterprise profits: Must we ask how the sausage is made?" Journal of Development Economics, 88: 19-31.

Dutt, N., O. Hawn, E. Vidal, A. Chatterji, A. McGahan, and W. Mitchell 2016 "How open system intermediaries address institutional failures: The case of business incubators in emerging-market countries." Academy of Management Journal, 59: 818-840.

Easterly, W. and R. Levine 1997 "Africa's growth tragedy: policies and ethnic divisions." Quarterly Journal of Economics, 112: 1203-1250.

Edmondson, A. C. 2012 "Teamwork on the fly." Harvard Business Review, 90: 72-80.

Edmondson, A. C., R. M. Bohmer, and G. P. Pisano 2001 "Disrupted routines: Team learning and new technology implementation in hospitals." Administrative Science Quarterly, 46: 685-716.

Edmondson, A. C. and Z. Lei 2014 "Psychological safety: The history, renaissance, and future of an interpersonal construct." Annual Review of Organizational Psychology and Organizational Behavior, 1: $23-43$.

Eisenhardt, K. M. and D. C. Galunic 2000 "Coevolving at last, a way to make synergies work." Harvard Business Review, 78: 91-91.

Feld, S. L.

1981 "The focused organization of social ties." American Journal of Sociology, 86: 10151035.

Field, E., S. Jayachandran, and R. Pande 2010 "Do traditional institutions constrain female entrepreneurship? A field experiment on business training in India." American Economic Review, 100: 125-129.

Gao, C., T. Zuzul, G. Jones, and T. Khanna 2017 "Overcoming Institutional Voids: A Reputation-Based View of Long-Run Survival." Strategic Management Journal, 38: 2147-2167.

George, G., C. Corbishley, J. N. Khayesi, M. R. Haas, and L. Tihanyi 2016a "Bringing Africa in: Promising directions for management research." Academy of Management Journal, 59: 377-393.

George, G., R. Kotha, P. Parikh, T. Alnuaimi, and A. S. Bahaj $2016 \mathrm{~b}$ "Social structure, reasonable gain, and entrepreneurship in Africa." Strategic Management Journal, 37: 1118-1131. 
Gibbons, R., R. Henderson, N. Repenning, and J. Sterman

2010 "What do managers do? Suggestive evidence and potential theories about building relationships." Handbook of Organizational Economics. Princeton, NJ: Princeton University Press.

Goffman, E.

1967 Interaction Ritual: Essays on Face-to-Face Interaction. Chicago, IL: Aldine Publishing Co.

Golub, B. and M. O. Jackson

2012 "How homophily affects the speed of learning and best-response dynamics."

Quarterly Journal of Economics, 127: 1287-1338.

Granovetter, M. S.

1973 "The Strength of Weak Ties." American Journal of Sociology, 78: 1360-1380.

Hallen, B. L.

2008 "The causes and consequences of the initial network positions of new organizations:

From whom do entrepreneurs receive investments?" Administrative Science Quarterly, 53: 685-718.

Hallen, B. L. and K. M. Eisenhardt

2012 "Catalyzing strategies and efficient tie formation: how entrepreneurial firms obtain investment ties." Academy of Management Journal, 55: 35-70.

Hansen, M. T., J. M. Podolny, and J. Pfeffer 2001 "So many ties, so little time: A task contingency perspective on corporate social capital in organizations." In S. M. Gabbay and R. Leenders (eds.), Social capital of organizations, 18: 21-57: Emerald Group Publishing Limited.

Hasan, S. and S. Bagde 2015 "Peers and network growth: Evidence from a natural experiment." Management Science, 61: 2536-2547.

Hasan, S. and R. Koning 2019a "Conversations and idea generation: Evidence from a field experiment." Research Policy, 48: 103811.

Hasan, S. and R. Koning 2019b "Prior ties and the limits of peer effects on startup team performance." Strategic Management Journal, 40: 1394-1416.

Hochberg, Y. V., A. Ljungqvist, and Y. Lu 2007 "Whom you know matters: Venture capital networks and investment performance." Journal of Finance, 62: 251-301.

Homans, G. C. 1961 "Human Behavior: Its Elementary Forms." New York: Harcourt, Brace and World, Inc.

Huang, K., M. Yeomans, A. W. Brooks, J. Minson, and F. Gino 2017 "It doesn't hurt to ask: Question-asking increases liking." Journal of personality and social psychology, 113: 430.

Ibarra, H. and M. Hunter 2007 "How leaders create and use networks." Harvard Business Review, 35: 101.

Ingram, P. and M. W. Morris 2007 "Do people mix at mixers? Structure, homophily, and the "life of the party"." Administrative Science Quarterly, 52: 558-585. 
Kacperczyk, A. J.

2013 "Social influence and entrepreneurship: The effect of university peers on entrepreneurial entry." Organization Science, 24: 664-683.

Katz, D. and R. L. Kahn

1978 The Social Psychology of Organizations. New York: John Wiley \& Sons, Inc.

Kellogg, K. C., W. J. Orlikowski, and J. Yates

2006 "Life in the trading zone: Structuring coordination across boundaries in postbureaucratic organizations." Organization Science, 17: 22-44.

Khanna, T. and K. G. Palepu 2010 Winning in Emerging Markets: A Road Map for Strategy and Execution. Cambridge: MA: Harvard Business Press.

Kim, P. H. and M. Li 2014 "Seeking assurances when taking action: Legal systems, social trust, and starting businesses in emerging economies." Organization Studies, 35: 359-391.

Kleinbaum, A. M., T. E. Stuart, and M. L. Tushman 2013 "Discretion within constraint: Homophily and structure in a formal organization." Organization Science, 24: 1316-1336.

Kogut, B. and U. Zander 1996 "What firms do? Coordination, identity, and learning." Organization Science, 7: $502-518$.

Krackhardt, D. and J. R. Hanson 1993 "Informal networks." Harvard Business Review, 71: 104-111.

Kuhn, K. M. and T. L. Galloway 2015 "With a little help from my competitors: Peer networking among artisan entrepreneurs." Entrepreneurship Theory and Practice, 39: 571-600.

Kuwabara, K., C. A. Hildebrand, and X. Zou 2018 "Lay Theories of Networking: How Laypeople's Beliefs About Networks Affect Their Attitudes Toward and Engagement in Instrumental Networking." Academy of Management Review, 43: 50-64.

Lee, M. Y., M. A. Mazmanian, and L. Perlow 2019 "Fostering Positive Relational Dynamics in Teams: The power of spaces and interaction scripts." Academy of Management Journal.

Luke, N. and K. Munshi 2006 "New roles for marriage in urban Africa: Kinship networks and the labor market in Kenya." Review of Economics and Statistics, 88: 264-282.

Marquis, C. and M. Raynard 2015 "Institutional strategies in emerging markets." Academy of Management Annals, 9: 291-335.

McFarland, D. A., D. Jurafsky, and C. Rawlings 2013 "Making the connection: Social bonding in courtship situations." American Journal of Sociology, 118: 1596-1649.

McFarland, D. A., J. Moody, D. Diehl, J. A. Smith, and R. J. Thomas 2014 "Network ecology and adolescent social structure." American Sociological Review, 79: 1088-1121.

McKenzie, D. and C. Woodruff 
2013 "What are we learning from business training and entrepreneurship evaluations around the developing world?" World Bank Research Observer, 29: 48-82.

McKenzie, D. and C. Woodruff

2018 "Business Practices in Small Firms in Developing Countries." Management Science, 63: 2967-2981.

McPherson, M., L. Smith-Lovin, and J. M. Cook

2001 "Birds of a feather: Homophily in social networks." Annual Review of Sociology, 27: 415-444.

Nanda, R. and T. Khanna

2010 "Diasporas and domestic entrepreneurs: Evidence from the Indian software industry." Journal of Economics \& Management Strategy, 19: 991-1012.

Neace, M. B.

1999 "Entrepreneurs in emerging economies: Creating trust, social capital, and civil

society." Annals of the American Academy of Political and Social Science, 565: 148-161.

O'Reilly III, C. A. and K. H. Roberts

1974 "Information filtration in organizations: Three experiments." Organizational

Behavior and Human Performance, 11: 253-265.

Paluck, E. L.

2011 "Peer pressure against prejudice: A high school field experiment examining social network change." Journal of Experimental Social Psychology, 47: 350-358.

Papke, L. E. and J. M. Wooldridge

2008 "Panel data methods for fractional response variables with an application to test pass rates." Journal of Econometrics, 145: 121-133.

Peng, Y.

2004 "Kinship networks and entrepreneurs in China's transitional economy." American Journal of Sociology, 109: 1045-1074.

Pierce, L. and J. A. Snyder

2017 "The historical slave trade and firm access to finance in Africa." Review of

Financial Studies, 31: 142-174.

Piezunka, H. and L. Dahlander

2019 "Idea rejected, tie formed: organizations' feedback on crowdsourced ideas."

Academy of Management Journal, 62: 503-530.

Ranganathan, A.

2018 "The artisan and his audience: Identification with work and price setting in a handicraft cluster in Southern India." Administrative Science Quarterly, 63: 637-667.

Reagans, R., E. Zuckerman, and B. McEvily 2004 "How to make the team: Social networks vs. demography as criteria for designing effective teams." Administrative Science Quarterly, 49: 101-133.

Reagans, R. E. and E. W. Zuckerman 2008 "Why knowledge does not equal power: The network redundancy trade-off." Industrial and Corporate Change, 17: 903-944.

Renzulli, L. A., H. Aldrich, and J. Moody 2000 "Family matters: Gender, networks, and entrepreneurial outcomes." Social Forces, 79: 523-546.

Rivera, M. T., S. B. Soderstrom, and B. Uzzi 
2010 "Dynamics of dyads in social networks: Assortative, relational, and proximity mechanisms." Annual Review of Sociology, 36: 91-115.

Rollag, K.

2015 "Managing Yourself Succeed in New Situations." Harvard Business Review, 93: $112-115$.

Ruef, M., H. E. Aldrich, and N. M. Carter 2003 "The structure of founding teams: Homophily, strong ties, and isolation among US entrepreneurs." American Sociological Review: 195-222.

Saxenian, A.

1990 "Regional networks and the resurgence of Silicon Valley." California Management Review, 33: 89-112.

Shane, S. and D. Cable 2002 "Network ties, reputation, and the financing of new ventures." Management Science, 48: 364-381.

Simon, H. A. 1991 "Bounded rationality and organizational learning." Organization Science, 2: 125 134.

Small, M. L.

2009 Unanticipated Gains: Origins of Network Inequality in Everyday Life. Oxford, UK: Oxford University Press.

Sorenson, O., J. W. Rivkin, and L. Fleming 2006 "Complexity, networks and knowledge flow." Research Policy, 35: 994-1017.

Srivastava, S. B., A. Goldberg, V. G. Manian, and C. Potts 2017 "Enculturation trajectories: Language, cultural adaptation, and individual outcomes in organizations." Management Science, 64: 1348-1364.

Stuart, T. E. and W. W. Ding 2006 "When do scientists become entrepreneurs? The social structural antecedents of commercial activity in the academic life sciences." American Journal of Sociology, 112: 97-144.

Stuart, T. E. and O. Sorenson 2007 "Strategic networks and entrepreneurial ventures." Strategic Entrepreneurship Journal, 1: 211-227.

Tushman, M. L. 1978 "Technical communication in R \& D laboratories: The impact of project work characteristics." Academy of Management Journal, 21: 624-645.

Tushman, M. L. 1979 "Managing communication networks in R\&D laboratories." Sloan Management Review, 20: 37.

Tushman, M. L. and R. Katz 1980 "External communication and project performance: An investigation into the role of Uzzi, B. gatekeepers." Management Science, 26: 1071-1085.

1996 "The sources and consequences of embeddedness for the economic performance of organizations: The network effect." American Sociological Review: 674-698.

Uzzi, B. and S. Dunlap

2005 "How to build your network." Harvard Business Review, 83: 53. 
Vissa, B.

2011 "A matching theory of entrepreneurs' tie formation intentions and initiation of economic exchange." Academy of Management Journal, 54: 137-158.

Vissa, B.

2012 "Agency in action: Entrepreneurs' networking style and initiation of economic exchange." Organization Science, 23: 492-510.

Weber, R. A. and C. F. Camerer

2003 "Cultural conflict and merger failure: An experimental approach." Management Science, 49: 400-415.

World Bank

2018 Doing Business: Togo. Washington, D.C.: International Bank for Reconstruction and Development

Yenkey, C. B.

2015 "Mobilizing a market: Ethnic segmentation and investor recruitment into the Nairobi Securities Exchange." Administrative Science Quarterly, 60: 561-595.

Zenger, T. R. and B. S. Lawrence

1989 "Organizational demography: The differential effects of age and tenure distributions on technical communication." Academy of Management Journal, 32: 353-376.

Zuckerman, E. W. and S. V. Sgourev

2006 "Peer capitalism: Parallel relationships in the US economy." American Journal of Sociology, 111: 1327-1366. 


\section{FIGURES AND TABLES}

Figure 1. Communication Practices Increase Information Exchange

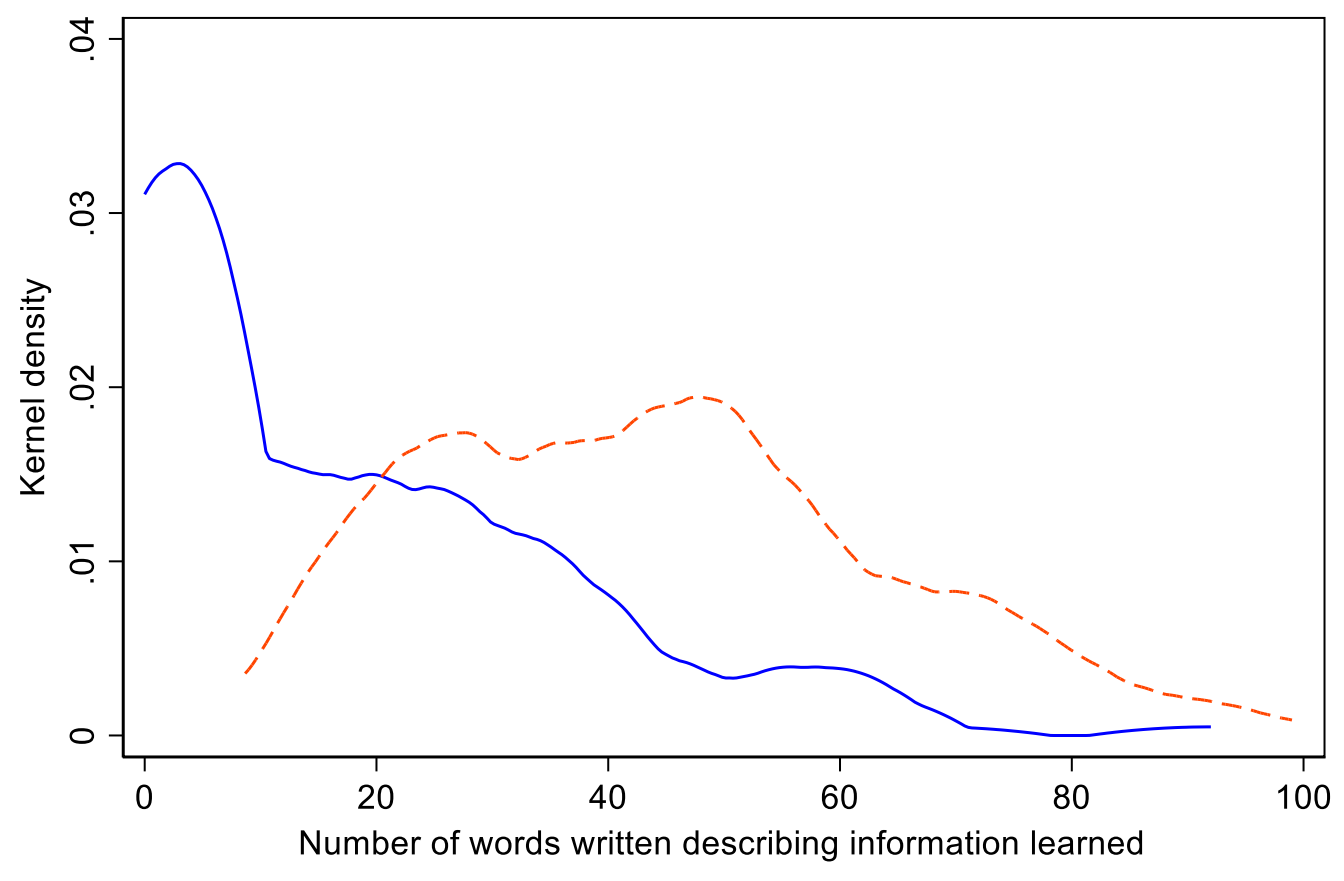

Control ----- Communication practices

The kernel density plots above compare the number of words written by entrepreneurs in the control and treatment groups. For entrepreneurs in the control group (blue solid line), the density is much higher at lower numbers of words, indicating that most entrepreneurs wrote fewer than 20 words when describing their exchanges with peers. By comparison, the density plot for entrepreneurs in the treatment group (red dashed line) is shifted to the right, with a median near 50 words, indicating that in general these entrepreneurs had more to describe after an interactions with peers. 
Figure 2. Communication Practices Increase Relationship Formation

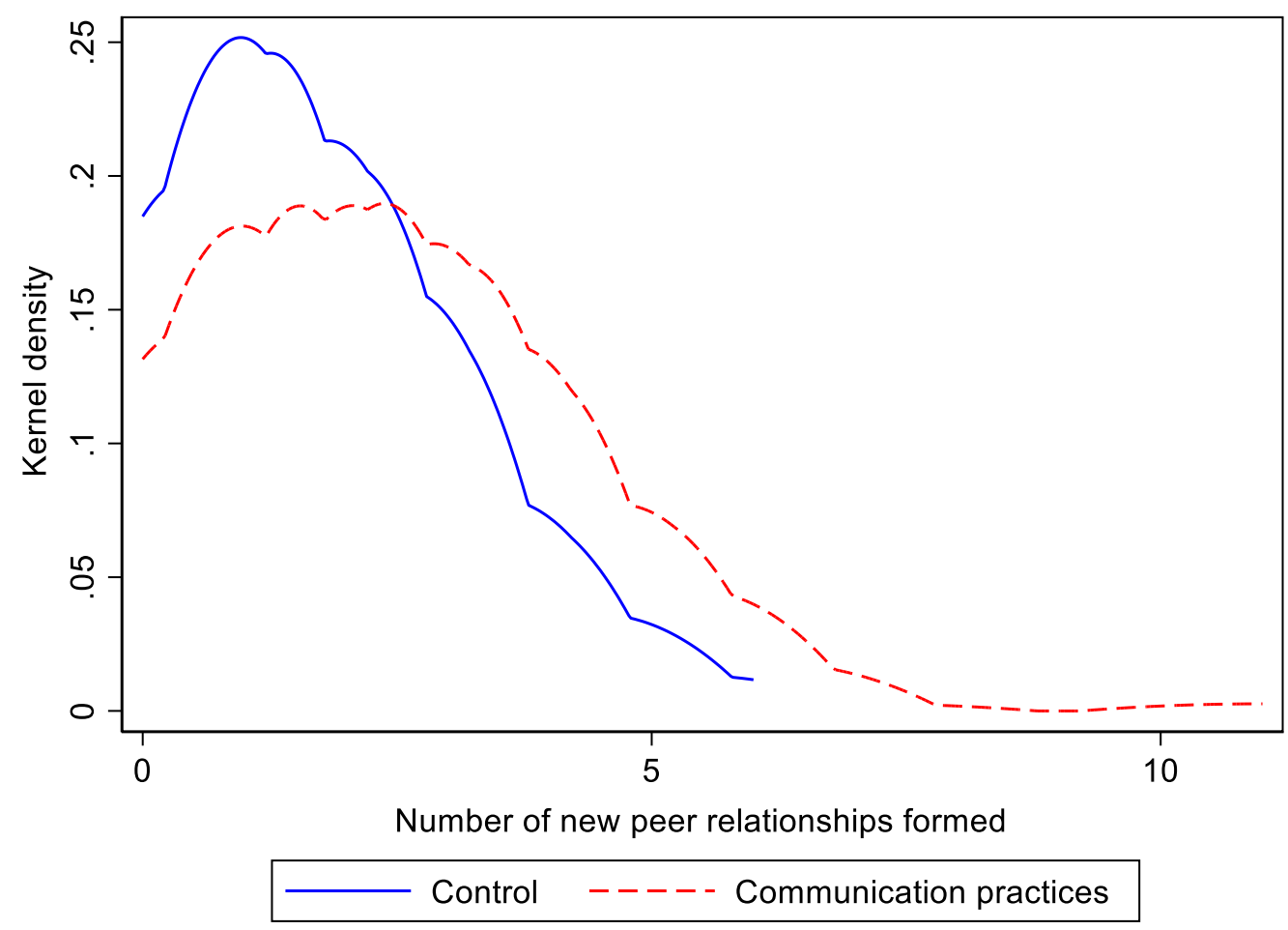

The kernel density plots above compare the number of relationships formed by entrepreneurs in the control group and in the communication practices treatment group. Relationships are measured six weeks after the completion of the training program. The density plot for entrepreneurs in the control group (blue solid line) is skewed to the left and peaks at about one relationship formed, while the plot for those in the treatment group (red dashed line) is shifted to the right of control group and peaks at about two relationships formed, indicating that entrepreneurs in the treatment formed more new relationships. 
Figure 3. Communication Practices Increased Profitability

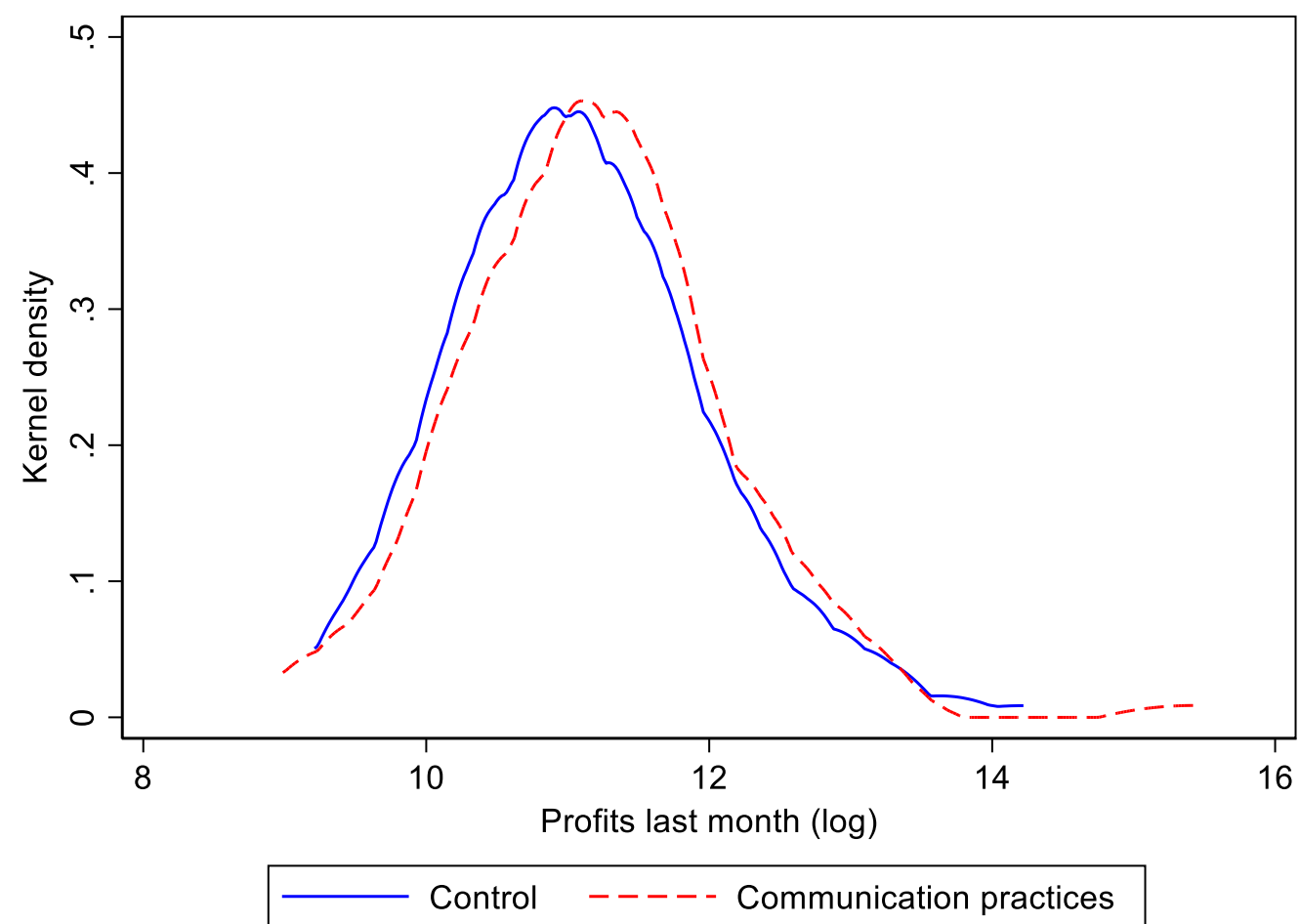

The kernel density plots above compare the logged profits in the last month earned by entrepreneurs in the control group and the treatment group, measured six months after the training program finished. The distribution of the profits for entrepreneurs in the treatment group (red dashed line) is shifted to the right of the distribution of profits for entrepreneurs in the control group (blue solid line). 
Table 1. Structure of Two-hour Presentation

\begin{tabular}{lll}
\hline Step & Duration & Content \\
\hline 1 & 20 minutes & $\begin{array}{l}\text { Information sharing: Taught how to ask questions and give advice. Learning } \\
\text { to communicate with others by asking about others' business activities, } \\
\text { struggles, challenges; offering advice based on own experience; sharing } \\
\text { common experiences; sharing insight and lessons. }\end{array}$ \\
2 & 20 minutes & $\begin{array}{l}\text { Identifying complementary others: Taught about reflecting on others. Involved } \\
\text { identifying whom to connect with; emphasizing alters that the actor doesn't } \\
\text { frequently have occasion to meet; initiating contact. }\end{array}$ \\
4 & 1 mour & $\begin{array}{l}\text { Sustaining communication: Taught how to follow up after initial interactions. } \\
\text { The focus was on creating opportunities to reconnect, exchanging contact } \\
\text { information; following up with contacts; the benefits of repeated contact. }\end{array}$ \\
& $\begin{array}{l}\text { Case study and questions: Examples of asking questions and giving advice, } \\
\text { identifying alters with complementary information, and following up. Case } \\
\text { discussion and commentary. Description of practical steps: how to talk to new } \\
\text { people, reaching out, following up. Questions and answers. }\end{array}$ \\
\hline
\end{tabular}


Table 2. Summary Statistics and Bivariate Correlations

\begin{tabular}{|c|c|c|c|c|c|c|c|c|c|c|c|c|c|c|c|c|}
\hline & & Mean & S.D. & 1 & 2 & 3 & 4 & 5 & 6 & 7 & 8 & 9 & 10 & 11 & 12 & 13 \\
\hline 1 & $\begin{array}{l}\text { Cooperative } \\
\text { perception of } \\
\text { interactions }\end{array}$ & 2.691 & 0.928 & & & & & & & & & & & & & \\
\hline 2 & $\begin{array}{l}\text { Information } \\
\text { exchange }\end{array}$ & 30.872 & 23.929 & 0.004 & & & & & & & & & & & & \\
\hline 3 & $\begin{array}{l}\text { Num. of } \\
\text { relationships } \\
\text { formed }\end{array}$ & 1.983 & 1.704 & 0.062 & 0.134 & & & & & & & & & & & \\
\hline 4 & $\begin{array}{l}\text { Skill } \\
\text { complementarity }\end{array}$ & 0.155 & 0.300 & 0.048 & 0.126 & 0.122 & & & & & & & & & & \\
\hline 5 & $\begin{array}{l}\text { Ethnic } \\
\text { concentration }\end{array}$ & 0.833 & 0.256 & -0.037 & -0.134 & -0.382 & -0.070 & & & & & & & & & \\
\hline 6 & $\begin{array}{l}\text { Profits at baseline } \\
(\log )\end{array}$ & 10.695 & 1.958 & 0.007 & -0.111 & -0.133 & 0.099 & 0.077 & & & & & & & & \\
\hline 7 & $\begin{array}{l}\text { Communication } \\
\text { practices }\end{array}$ & 0.518 & 0.500 & 0.131 & 0.571 & 0.229 & 0.134 & -0.170 & -0.135 & & & & & & & \\
\hline 8 & Ewe ethnicity & 0.781 & 0.414 & -0.008 & 0.099 & 0.188 & 0.039 & 0.031 & 0.042 & 0.015 & & & & & & \\
\hline 9 & Female & 0.355 & 0.479 & 0.057 & 0.021 & 0.042 & -0.089 & -0.005 & -0.134 & 0.059 & -0.083 & & & & & \\
\hline 10 & $\begin{array}{l}\text { Completed } \\
\text { primary school }\end{array}$ & 0.748 & 0.435 & -0.076 & -0.022 & -0.001 & -0.085 & -0.108 & -0.069 & -0.107 & -0.112 & 0.006 & & & & \\
\hline 11 & Employees (log) & 1.701 & 3.361 & -0.054 & -0.052 & -0.105 & -0.084 & 0.105 & 0.276 & -0.023 & -0.049 & -0.060 & -0.047 & & & \\
\hline 12 & Firm age & 10.590 & 7.649 & 0.002 & 0.070 & 0.095 & 0.108 & 0.096 & 0.085 & 0.113 & 0.234 & 0.019 & -0.410 & 0.090 & & \\
\hline 13 & $\begin{array}{l}\text { Management } \\
\text { practices score }\end{array}$ & 0.577 & 0.266 & 0.004 & 0.040 & 0.065 & 0.189 & 0.023 & 0.275 & 0.033 & 0.077 & 0.017 & -0.126 & 0.298 & 0.261 & \\
\hline 14 & Class size & 23.465 & 2.777 & 0.084 & 0.297 & 0.123 & -0.092 & -0.035 & -0.178 & 0.397 & 0.057 & 0.076 & -0.013 & -0.152 & -0.001 & -0.114 \\
\hline
\end{tabular}

$* \mathrm{~N}=301$ except for profits at baseline, which has an $\mathrm{N}$ of 273 . This is because 28 participants had not tallied revenue and costs before the baseline survey. 
Table 3. Negative Binomial Regressions Show Communication Practices Increase Entrepreneurs' Cooperative Perceptions and the Amount of Information Exchanged

\begin{tabular}{|c|c|c|c|c|}
\hline & \multicolumn{2}{|c|}{ Cooperative perception } & \multicolumn{2}{|c|}{ Information exchange } \\
\hline & $(1)$ & (2) & (3) & (4) \\
\hline Communication practices & & $\begin{array}{l}0.098 * \\
(0.044)\end{array}$ & & $\begin{array}{l}1.012 * * \\
(0.260)\end{array}$ \\
\hline Ewe ethnicity & $\begin{array}{l}-0.016 \\
(0.055)\end{array}$ & $\begin{array}{l}-0.012 \\
(0.053)\end{array}$ & $\begin{array}{c}0.069 \\
(0.114)\end{array}$ & $\begin{array}{c}0.081 \\
(0.095)\end{array}$ \\
\hline Female & $\begin{array}{c}0.072 \\
(0.041)\end{array}$ & $\begin{array}{c}0.072 \\
(0.040)\end{array}$ & $\begin{array}{l}-0.013 \\
(0.089)\end{array}$ & $\begin{array}{l}-0.074 \\
(0.115)\end{array}$ \\
\hline Completed primary school & $\begin{array}{l}-0.061 \\
(0.046)\end{array}$ & $\begin{array}{l}-0.049 \\
(0.044)\end{array}$ & $\begin{array}{c}0.022 \\
(0.112)\end{array}$ & $\begin{array}{c}0.121 \\
(0.081)\end{array}$ \\
\hline Employees (log) & $\begin{array}{l}-0.003 \\
(0.007)\end{array}$ & $\begin{array}{l}-0.003 \\
(0.007)\end{array}$ & $\begin{array}{l}-0.002 \\
(0.017)\end{array}$ & $\begin{array}{c}0.004 \\
(0.014)\end{array}$ \\
\hline Firm age & $\begin{array}{c}0.000 \\
(0.003)\end{array}$ & $\begin{array}{l}-0.001 \\
(0.004)\end{array}$ & $\begin{array}{c}0.003 \\
(0.007)\end{array}$ & $\begin{array}{l}-0.008 \\
(0.009)\end{array}$ \\
\hline Management practices score & $\begin{array}{c}0.057 \\
(0.079)\end{array}$ & $\begin{array}{c}0.048 \\
(0.071)\end{array}$ & $\begin{array}{c}0.124 \\
(0.182)\end{array}$ & $\begin{array}{l}-0.037 \\
(0.219)\end{array}$ \\
\hline Class size & $\begin{array}{l}0.013 * \\
(0.007)\end{array}$ & $\begin{array}{c}0.006 \\
(0.007)\end{array}$ & $\begin{array}{c}0.118 \\
(0.061)\end{array}$ & $\begin{array}{c}0.051 \\
(0.043)\end{array}$ \\
\hline $\begin{array}{l}\text { Sector fixed effects } \\
\text { Likelihood ratio } \chi^{2}\end{array}$ & $\begin{array}{c}\text { Yes } \\
39.580^{* *}\end{array}$ & $\begin{array}{c}\text { Yes } \\
152.570^{* *}\end{array}$ & $\begin{array}{c}\text { Yes } \\
24.950 * *\end{array}$ & $\begin{array}{c}\text { Yes } \\
77.510^{* *}\end{array}$ \\
\hline$N$ & 301 & 301 & 303 & 303 \\
\hline
\end{tabular}

All models estimated using negative binomial regression. The outcome variable in Models 1 and 2 is the number of cooperative words selected by each participant to describe interactions. The outcome variable in Models 3 and 4 is the number of words written by individual participants during the networking session, during which they spoke to three randomly selected peer entrepreneurs. Constant estimated in each model but not shown. Robust standard errors clustered at the training-class level in parentheses. ${ }^{* *} p<0.01$, * $p<0.05$ 
Table 4. Regressions Show Communication Practices Increase the Number of Relationships Formed, Increase the Proportion of Relationships Formed that are Skill-Complementary, and Reduce the Level of Ethnic Concentration in Relationships Formed

\begin{tabular}{|c|c|c|c|c|c|c|}
\hline & \multicolumn{2}{|c|}{$\begin{array}{l}\text { Relationships } \\
\text { formed }\end{array}$} & \multicolumn{2}{|c|}{ Skill complementarity } & \multicolumn{2}{|c|}{ Ethnic concentration } \\
\hline & $(1)$ & $(2)$ & $(3)$ & (4) & $(5)$ & $(6)$ \\
\hline Communication practices & & $\begin{array}{l}0.360 * \\
(0.155)\end{array}$ & & $\begin{array}{l}1.036 * \\
(0.417)\end{array}$ & & $\begin{array}{c}-0.870 * * \\
(0.178)\end{array}$ \\
\hline Ewe ethnicity & $\begin{array}{c}0.373 * * \\
(0.116)\end{array}$ & $\begin{array}{c}0.372 * * \\
(0.116)\end{array}$ & $\begin{array}{c}0.206 \\
(0.321)\end{array}$ & $\begin{array}{c}0.220 \\
(0.340)\end{array}$ & $\begin{array}{l}-0.038 \\
(0.247)\end{array}$ & $\begin{array}{l}-0.053 \\
(0.258)\end{array}$ \\
\hline Female & $\begin{array}{l}-0.044 \\
(0.158)\end{array}$ & $\begin{array}{l}-0.010 \\
(0.155)\end{array}$ & $\begin{array}{l}-1.633 \\
(1.122)\end{array}$ & $\begin{array}{l}-1.495 \\
(0.973)\end{array}$ & $\begin{array}{l}-0.336 \\
(0.482)\end{array}$ & $\begin{array}{l}-0.407 \\
(0.390)\end{array}$ \\
\hline Completed primary school & $\begin{array}{c}0.043 \\
(0.142)\end{array}$ & $\begin{array}{c}0.074 \\
(0.138)\end{array}$ & $\begin{array}{l}-0.138 \\
(0.368)\end{array}$ & $\begin{array}{l}-0.031 \\
(0.377)\end{array}$ & $\begin{array}{c}-0.536^{* *} \\
(0.193)\end{array}$ & $\begin{array}{c}-0.656 * * \\
(0.219)\end{array}$ \\
\hline Employees (log) & $\begin{array}{l}-0.020 \\
(0.020)\end{array}$ & $\begin{array}{l}-0.022 \\
(0.020)\end{array}$ & $\begin{array}{c}-0.172 * * \\
(0.051)\end{array}$ & $\begin{array}{c}-0.187 * * \\
(0.051)\end{array}$ & $\begin{array}{l}0.093 * \\
(0.038)\end{array}$ & $\begin{array}{l}0.102 * \\
(0.042)\end{array}$ \\
\hline Firm age & $\begin{array}{c}0.005 \\
(0.004)\end{array}$ & $\begin{array}{c}0.003 \\
(0.004)\end{array}$ & $\begin{array}{l}0.017^{*} \\
(0.008)\end{array}$ & $\begin{array}{c}0.012 \\
(0.011)\end{array}$ & $\begin{array}{c}0.000 \\
(0.011)\end{array}$ & $\begin{array}{c}0.006 \\
(0.010)\end{array}$ \\
\hline Management practices score & $\begin{array}{c}0.228 \\
(0.252)\end{array}$ & $\begin{array}{c}0.214 \\
(0.253)\end{array}$ & $\begin{array}{l}1.642 * * \\
(0.525)\end{array}$ & $\begin{array}{l}1.596^{* * *} \\
(0.521)\end{array}$ & $\begin{array}{l}-0.214 \\
(0.465)\end{array}$ & $\begin{array}{l}-0.212 \\
(0.445)\end{array}$ \\
\hline Class size & $\begin{array}{c}0.027 \\
(0.022)\end{array}$ & $\begin{array}{l}-0.002 \\
(0.026)\end{array}$ & $\begin{array}{l}-0.092 \\
(0.048)\end{array}$ & $\begin{array}{c}-0.177 * * \\
(0.045)\end{array}$ & $\begin{array}{l}-0.009 \\
(0.050)\end{array}$ & $\begin{array}{c}0.060 \\
(0.042)\end{array}$ \\
\hline $\begin{array}{l}\text { Sector fixed effects } \\
\text { Wald } \chi^{2}\end{array}$ & $\begin{array}{c}\text { Yes } \\
42.14^{* *}\end{array}$ & $\begin{array}{c}\text { Yes } \\
56.45^{* *}\end{array}$ & $\begin{array}{c}\text { Yes } \\
190.06 * *\end{array}$ & $\begin{array}{c}\text { Yes } \\
200.40 * *\end{array}$ & $\begin{array}{c}\text { Yes } \\
515.39 * *\end{array}$ & $\begin{array}{c}\text { Yes } \\
432.68 * *\end{array}$ \\
\hline$N$ & 301 & 301 & 301 & 301 & 301 & 301 \\
\hline
\end{tabular}

Models 1 and 2 are estimated using negative binomial regressions. The outcome variable in these models is the number of peer business relationships to other participants from the same class that each entrepreneur formed six weeks after the training program. The remaining models in the table were estimated using fractional logit regressions. The outcome variable in Models 3 and 4 is the proportion of all relationships formed that exhibit skill complementarity. The outcome variable in Models 5 and 6 is the Herfindahl index of concentration among ethnic groups of the relationships formed. Constant is estimated in all models but not reported. Robust standard errors, clustered at the training-class level, are in parentheses. $* * p<0.01, * p<0.05$ 
Table 5. Fixed Effects Regressions Show Communication Practices Increase Entrepreneurs' Profits in the Last Month

(1) (2)

Communication practices X Post-treatment period

$\begin{array}{cc}0.553^{*} & 0.671^{*} \\ (0.265) & (0.281) \\ -0.143 & -0.078 \\ (0.199) & (0.214) \\ -0.467 & \\ (0.273) & \end{array}$

Ewe ethnicity

Post-treatment period

Female

$-0.223$

$(0.184)$

Completed primary school

$-0.047$

$(0.180)$

Employees $(\log )$

$0.089^{*}$

$(0.039)$

Firm age

0.007

$(0.011)$

Management practices score

$0.945^{* *}$

Class size

$(0.276)$

$-0.053$

(0.030)

Entrepreneur fixed effects

Sector fixed effects

No

Yes

Yes

Yes

Survey wave fixed effects

$4.930^{* *} \quad 3.690^{*}$

F-statistic

812

812

The outcome variable in both models is entrepreneurs' logged profits during the last month. The post-treatment period is an indicator variable for the survey waves after the treatment was administered. Three survey waves are included in these analyses, the baseline, first follow-up six weeks after the training, and second follow-up six months after the training. Robust standard errors clustered at the training-class level are in parentheses. ${ }^{*} p<0.01$, * $p<0.05$ 


\section{Appendix}

The value of communication:

Evidence from a field experiment with entrepreneurs in Togo 
APPENDIX A: Togo, qualitative data, and field experimental procedures

\section{Togo}

Togo is a small country in West Africa, with a population of approximately seven million people, about two million of whom reside in the capital Lomé. It is bordered on the west by Ghana, on the east by Benin, and on the north by Burkina Faso, to the south it rests on the Gulf of Guinea. As a former French colony, the main language for business is French. Togo became an independent country in 1960, but since then it has been largely isolated from the international community due to the dictatorial political regime and the human rights abuses the regime has committed. This has changed since 2005 , when a new president was elected, which has in turn led to a decade of slow but steady economic growth. Despite this progress, Togo remains an income poor country. In terms of per capita income at purchasing power parity it ranks 207th of 216 countries (World Bank, 2018). Similarly, the UN's Human Development Index (2017) ranks Togo 166th of 188 countries. Over 54 percent of the population lives under the poverty line of $\$ 1.90$ per day and the mean years of schooling for inhabitants is 4.7 years (United Nations Development Programme, 2017).

Togo is made up of multiple ethnic groups. The majority ethnic group in the south of the country is the Ewe group, whereas in the north it is the Kabiye group. Beyond these two main groups there are also significant populations of the Ana, Yoruba, and Kotokoli ethnic groups.

\section{Qualitative data on entrepreneurs in Togo}

During three trips to Lomé between 2015 and 2017 one of the authors conducted 47 semistructured interviews with local entrepreneurs, each of which lasted between 30 and 90 minutes. Interviews included entrepreneurs at every stage of growth, from recently launched to several decades in business. The distribution of interviews was 17 micro businesses, 18 small businesses, and 12 medium businesses. The sample of entrepreneurs also covered a diverse array of sectors, including food processing, construction, clothing manufacturing, and electronics.

To build the sample the author used a staggered referral approach (Small, 2009). The starting point were several local nonprofit associations whose social mission was the promotion of entrepreneurship. From there, he increased the sample by asking interviewees for suggestions of other entrepreneurs to approach. This approach was appropriate in this context because there were no public listings of businesses in Lomé and experienced entrepreneurs rarely trusted strangers enough to grant interviews without an introduction from someone they know. As a result, this approach was successful in completing a substantial number of interviews.

The author used a grounded theory approach in their interviews (Charmaz, 2014). They began with general questions about what entrepreneurs felt were significant challenges in doing business in Togo and what they feel were important ways of overcoming those challenges. At the outset we were agnostic as to the specific challenges that entrepreneurs faced and the ways in which they might approach overcoming them. However, after the first few interviews a pattern quickly emerged around the formation of new business relationships. Specifically, it emerged that forming relationships was a complex process for entrepreneurs. Many complained about feeling isolated and having to manage the difficulties of doing business in Togo alone. Probing 
further on this theme revealed that entrepreneurs were largely aware of the value of peer relationships to other entrepreneurs, but they often struggled with connecting with new acquaintances. As a result, their portfolios of relationships were highly concentrated among family, neighbors, and childhood friends. Talking to entrepreneurs revealed that the process of connecting was often sidetracked because they were unable to get to the point where they could talk about their businesses or develop a foundation of mutual respect and trust. This revealed to us that there were significant communication problems between entrepreneurs who previously did not know each other. There was a need to structure the communication process in a way that would enable entrepreneurs to get to talking about their businesses, their opportunities, and their challenges. This formed a significant insight into thinking about this field experiment and designing the intervention.

\section{Field experimental procedures}

The setting for the field experiment was the business training program "Marketing in Action." The offices of the business training program were based in the suburb of Kegue, in Lomé. At these offices, we registered all participants between the first and thirty-first of March 2017. The first group of participants began their training on April $3^{\text {rd }} 2017$ and the last group finished their training on May $18^{\text {th }}$. After the end of the training program the offices remained open for several months in case any of the participants had questions or comments.

One author was present during the entirety of the training program in order to ensure that the registration of participants, the randomization into the treatment, the teaching of the program, and the discussion of communication practices were done correctly. In addition to the author, there were three full-time employees: one administrative assistant and two instructors. The administrative assistant helped manage the registration process and organize the teaching space during the training. The two instructors were consultants from Lomé, who had previously taught similar training programs to Togolese entrepreneurs at the local university and in programs organized by the World Bank. The instructors were intimately familiar with the teaching material and how to convey them appropriately to local entrepreneurs. Finally, to help with the recruitment of participants, three local university students were hired to walk through the main business districts of Lomé and advertise the training program to business owners. In addition to this canvassing, we also advertised the training program to local entrepreneurs through a number of local nonprofits, incubators, business associations, facebook pages, and WhatsApp groups. The canvassing and advertising produced 326 registrants into the training program.

Data collection was built around four different time points in the field experiment. A pretreatment survey was administered as individuals arrived to the first day of the training programs. At the end of the second day of the training program, participants were given a training program exit survey, which included questions related to their experience during the training program, their interactions with others, and a word-map for the word selection exercise. The third data collection point occurred six weeks after the training program, between May and June 2017. Instructors followed-up in person with the participants to survey them at the location of their business. It was important for the instructors to survey them and not a third party because there was an important bond of trust between the instructors and participants, which makes the answers to the survey more accurate and reliable. Instructors were able to follow-up with 303 participants of the 316 who completed the training. Finally, the last point of data collection was 
the second follow-up survey, which took place six months after the training program, from November to December, 2017. Instructors were able to survey 301 of 303 participants in the second follow-up survey. Figure A1, below, shows the geographic distribution of the 301 entrepreneur participants across the city of Lomé that completed the training program and the follow-up surveys. It is worth noting that the broad canvassing and online advertising produced a geographically diverse set of participants.

Figure A1: Approximate geographic location of study participants

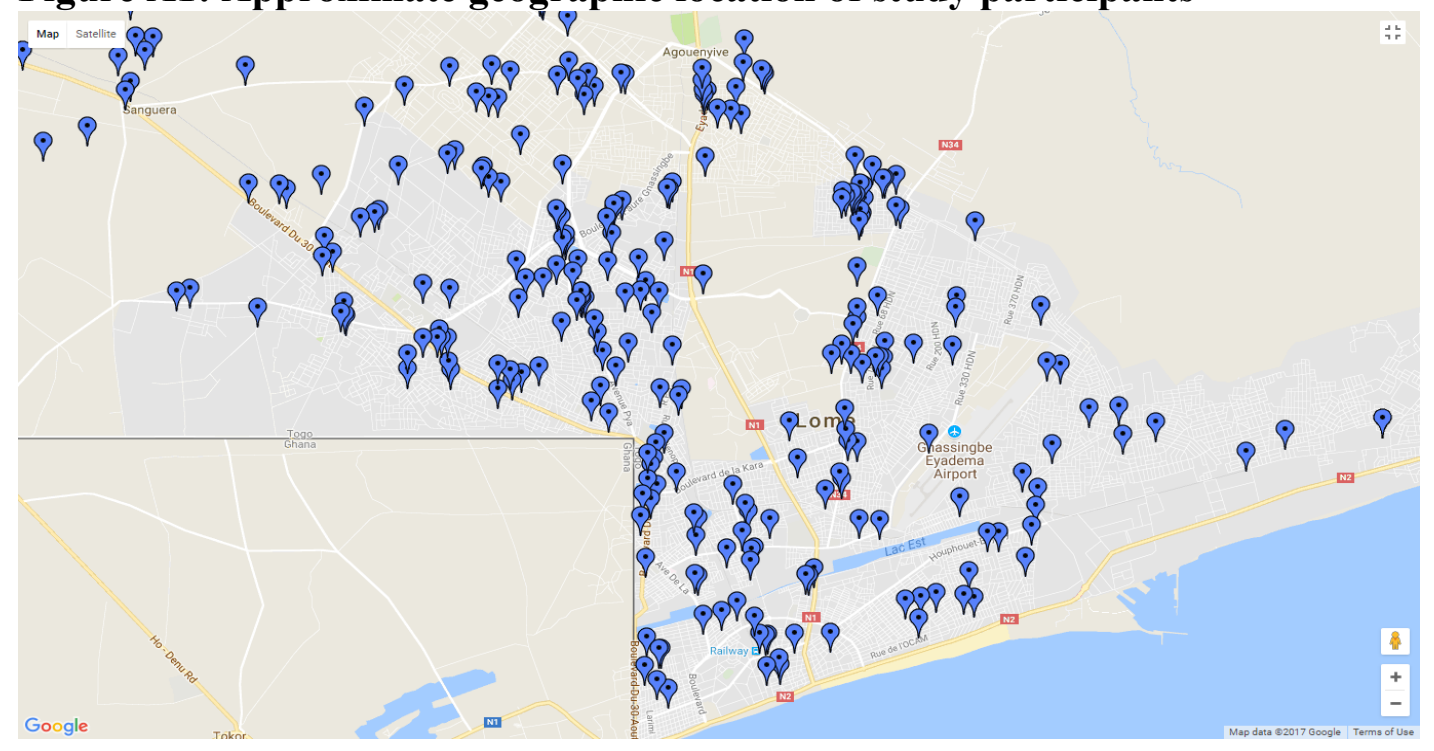




\section{APPENDIX B: Balance Test}

To test the balance of our randomization we ran a series of logit regressions, which are presented in Table B1. In each model the treatment, a binary variable indicating whether an entrepreneur was exposed to the communication practices treatment, is regressed on variables that capture entrepreneur and business characteristics. Models 1 to 7 test each characteristic on its own, while Model 8 tests all variables simultaneously. None of the coefficients in any of the models are statistically significant at conventional levels. This indicates that none of the entrepreneurs' or their businesses' characteristics are associated with receiving the treatment and that therefore the randomization of the treatment was successful, producing balanced control and treatment groups.

Table B1: Balance tests checking if pre-treatment entrepreneur characteristics predict whether the entrepreneurs ends up in the communication practices treatment arm.

$\begin{array}{llllllll}(1) & (2) & (3) & (4) & \text { (5) } & \text { (6) } & \text { (7) } & \text { (8) }\end{array}$

$\begin{array}{lc}\text { Ewe ethnicity } & 0.136 \\ & (0.402)\end{array}$

Female

0.320

$(0.237)$

$(6)+(8)$

Completed primary school

$-0.628$

$(0.432)$

Employees (log)

$-0.027$

$(0.073)$

Firm age

Management practices score

0.043

(0.037)

0.504

(1.035)

$-0.204$

(0.415)

0.098

(0.165)

$-0.444$

(0.447)

$-0.030$

(0.053)

0.038

(0.031)

0.650

(0.716)

Class size

$0.368 \quad 0.380$

(0.257) (0.263)

$\begin{array}{lllllllll}N & 301 & 301 & 301 & 301 & 301 & 301 & 301 & 301\end{array}$

All models are estimated using logit regressions. The outcome variable in all models is a binary indicator of whether the entrepreneur received the treatment of communication practices. A constant is estimated in each model but not shown. Robust standard errors clustered at the training class level are in parentheses. $* * p<0.01, * p<0.05$ 


\section{APPENDIX C: Interpreting performance effects}

The graphical interpretation of performance effects can be difficult. In our study we plotted the difference in business performance between the control group and the treatment group using a kernel density plot in Figure 3. What is noteworthy about the plot is that the entire distribution of profits is shifted to the right, which means that entrepreneurs at every earnings level increased their performance. This represents a large substantive shift in performance, which, however, translates into only slight graphical changes. To help interpret our Figure 3, it helps to refer to the equivalent plot published in Cai and Szeidl (2017), reproduced here below in Figure C1. This plot contrasts the performance of their control and treatment groups at the end of their field experiment, where the treatment increased businesses' performance by 8.1 percent. As can be seen in Figure C1, the visual difference in the distribution of profits for treatment and control is relatively small, yet, as in our case, the substantive effect was large.

Figure C1: Kernel density of log sales (Cai and Szeidl 2017, 1246)

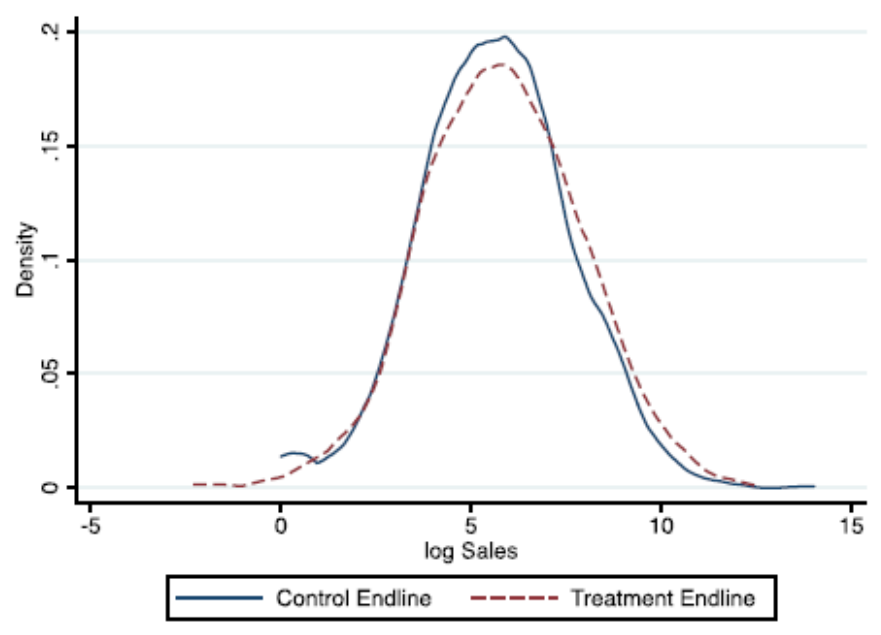




\section{APPENDIX D: Validating skill complementarity using simulations}

A potential concern with our results is that the treatment led to more skill complementary simply a byproduct of entrepreneurs forming more relationships. To show that the observed increases in skill complementarity in entrepreneurs' relationships in the treatment group are driven by the communication practices and not by the fact that they form more new relationships we ran a series of simulations. The simulation is meant to show what entrepreneurs' levels of skill complementarity would be if they were randomly forming relationships with others in their training class but still forming the same number of relationships. This allows us to rule out the possibility that our treatment did not change the types of people sought out as advice partners.

Our simulation begins with the real data we gathered on participating entrepreneurs. For each entrepreneur we know the number of business relationships they formed and the co-participants they formed them with. For the simulation, we take each entrepreneur and the number of relationships they formed and we direct these to a new set of randomly selected co-participants from within their training class. For each such simulation, we estimate the difference between the treated entrepreneurs and the control group entrepreneurs. We repeat this simulation process 2,000 times and this produces a distribution of values for the difference between the simulated control and treatment groups. In the actual data, the difference between the treatment group and the control group for skill complementarity was positive. If this was driven by non-random matching, we should not observe the same magnitude of difference between the control and treatment group in levels of skill complementarity.

Figure D1 plots the distribution of the simulated values of the difference between control and treatment groups in the skill complementarity of entrepreneurs' relationships. The vertical dashed line shows the observed difference in task complementarity between the treatment and control groups. As the figure shows, all the simulated values are substantially below the observed value and near zero. The mean value of the difference in skill complementarity for the simulated data are not statistically different from zero. 
Figure D1: Simulated and observed difference between control and treatment group in proportion of skill complementary relationships

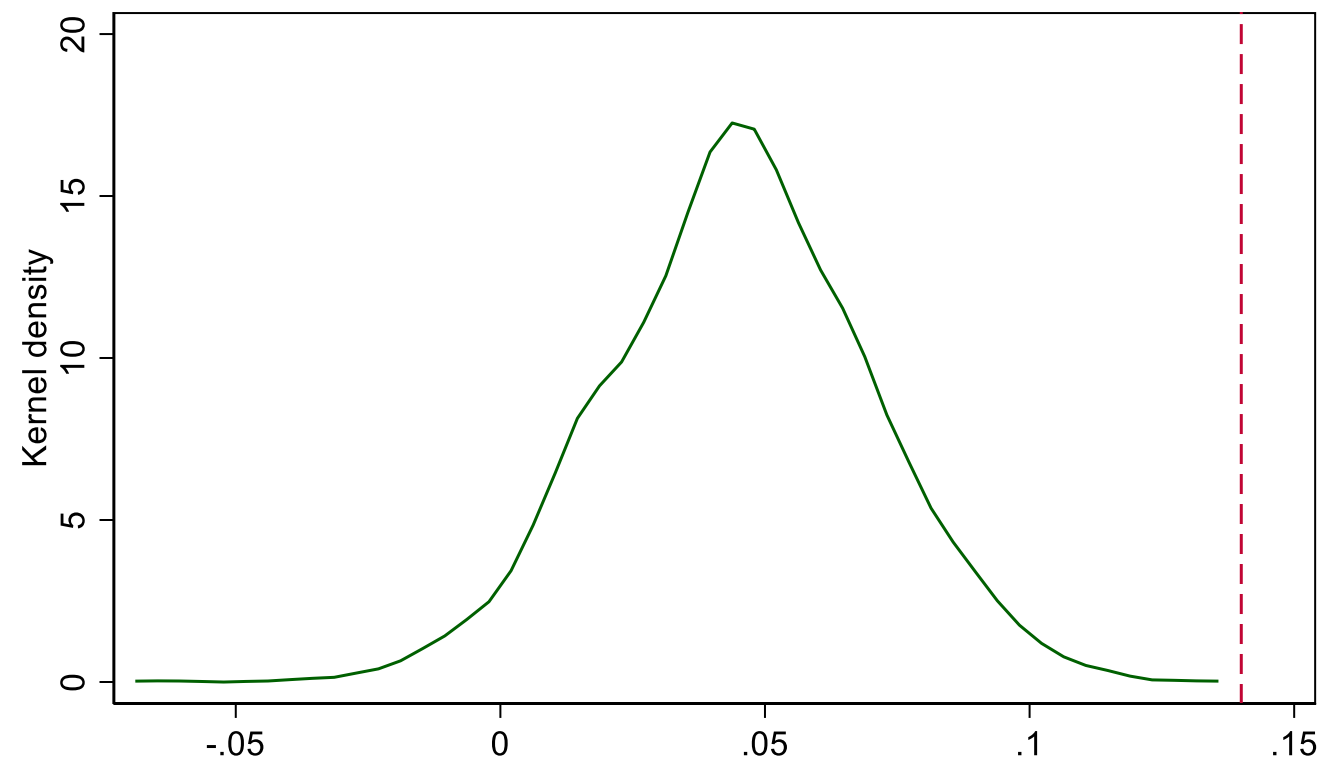

Difference between control and treatment groups in the proportion of ties that are skill complementary

$$
\begin{aligned}
& \text { Simulated differences } \\
& ---- \text { Observed difference }
\end{aligned}
$$




\section{APPENDIX E: Estimating models using linear regression}

In Tables E1 and E2 we replicate our results from Tables 3 and 4 in the paper using ordinary least squares (OLS) regressions in place of the negative binomial and fractional logit regressions. Replicating the results using OLS helps show that the key results of the paper are not model dependent and therefore more robust.

The coefficients in Tables E1 and E2 replicate closely the results in Tables 3 and 4 respectively. The coefficient signs and levels of statistical significance are comparable, as are the interpretations of their magnitudes.

Table E1: OLS regressions explaining the number of cooperative words chosen and the amount of information exchanged

Cooperative perceptions Information exchange

(1)

Communication practices

Ewe ethnicity

Female

Completed primary school

Employees (log)

Firm age

Management practices score

Class size

Sector fixed effects

F-statistic

N

$0.84^{*}$

301
(2)

(3)
$26.849 * *$

$$
(0.125)
$$

2.035

(2.614)

$-0.956$

(2.215)

2.686

(2.563)

$-0.120$

$(0.453)$

$-0.047$

$(0.135)$

2.649

(4.606)

0.669

(0.646)

(0.166)

$0.136 \quad 4.966$

(5.050)

0.017

$(1.305)$

$(0.018)$

Yes

$2.67^{* *}$

Yes

$1.07^{* *}$

$10.05^{* *}$

301

301

301

All models estimated using OLS. The outcome variable in Models 1 and 2 is the number of cooperative words selected by each participant to describe interactions. The outcome variable in Models 3 and 4 is the number of words written by each participant during the networking session, during which they spoke to three randomly selected peer entrepreneurs. Constant estimated in each model but not shown. Robust standard errors clustered at the training class level in parentheses. ${ }^{* *} p<0.01,{ }^{*} p<0.05$ 
Table E2: OLS regressions estimating the number of relationships formed, proportion of relationships formed that are skill complementary, and ethnic concentration of relationships formed

\begin{tabular}{|c|c|c|c|c|c|c|}
\hline & \multicolumn{2}{|c|}{$\begin{array}{l}\text { Relationships } \\
\text { formed }\end{array}$} & \multicolumn{2}{|c|}{$\begin{array}{c}\text { Skill } \\
\text { complementarity }\end{array}$} & \multicolumn{2}{|c|}{$\begin{array}{c}\text { Ethnic } \\
\text { concentration }\end{array}$} \\
\hline & (1) & (2) & (3) & (4) & (5) & (6) \\
\hline Communication practices & & $\begin{array}{c}0.678^{* *} \\
(0.196)\end{array}$ & & $\begin{array}{l}0.109^{*} \\
(0.048)\end{array}$ & & $\begin{array}{c}-0.108 * * \\
(0.028)\end{array}$ \\
\hline Ewe ethnicity & $\begin{array}{l}0.599 * * \\
(0.220)\end{array}$ & $\begin{array}{l}0.609^{* *} \\
(0.218)\end{array}$ & $\begin{array}{c}0.026 \\
(0.033)\end{array}$ & $\begin{array}{c}0.028 \\
(0.034)\end{array}$ & $\begin{array}{l}-0.004 \\
(0.034)\end{array}$ & $\begin{array}{l}-0.006 \\
(0.034)\end{array}$ \\
\hline Female & $\begin{array}{l}-0.109 \\
(0.509)\end{array}$ & $\begin{array}{l}-0.044 \\
(0.521)\end{array}$ & $\begin{array}{l}-0.098 \\
(0.059)\end{array}$ & $\begin{array}{l}-0.088 \\
(0.046)\end{array}$ & $\begin{array}{l}-0.045 \\
(0.068)\end{array}$ & $\begin{array}{l}-0.055 \\
(0.054)\end{array}$ \\
\hline Completed primary school & $\begin{array}{c}0.081 \\
(0.244)\end{array}$ & $\begin{array}{c}0.152 \\
(0.243)\end{array}$ & $\begin{array}{l}-0.022 \\
(0.051)\end{array}$ & $\begin{array}{l}-0.010 \\
(0.049)\end{array}$ & $\begin{array}{l}-0.060^{*} \\
(0.022)\end{array}$ & $\begin{array}{c}-0.071^{* *} \\
(0.024)\end{array}$ \\
\hline Employees (log) & $\begin{array}{l}-0.036 \\
(0.042)\end{array}$ & $\begin{array}{l}-0.041 \\
(0.042)\end{array}$ & $\begin{array}{c}-0.021^{* *} \\
(0.007)\end{array}$ & $\begin{array}{c}-0.022^{* *} \\
(0.007)\end{array}$ & $\begin{array}{l}0.012^{*} \\
(0.005)\end{array}$ & $\begin{array}{l}0.013^{*} \\
(0.005)\end{array}$ \\
\hline Firm age & $\begin{array}{c}0.012 \\
(0.014)\end{array}$ & $\begin{array}{c}0.008 \\
(0.014)\end{array}$ & $\begin{array}{l}0.003^{*} \\
(0.001)\end{array}$ & $\begin{array}{c}0.002 \\
(0.001)\end{array}$ & $\begin{array}{c}0.000 \\
(0.002)\end{array}$ & $\begin{array}{c}0.001 \\
(0.001)\end{array}$ \\
\hline Management practices score & $\begin{array}{c}0.435 \\
(0.393)\end{array}$ & $\begin{array}{c}0.431 \\
(0.385)\end{array}$ & $\begin{array}{l}0.201^{*} \\
(0.077)\end{array}$ & $\begin{array}{l}0.201^{*} \\
(0.072)\end{array}$ & $\begin{array}{l}-0.021 \\
(0.067)\end{array}$ & $\begin{array}{l}-0.020 \\
(0.063)\end{array}$ \\
\hline Class size & $\begin{array}{c}0.053 \\
(0.032)\end{array}$ & $\begin{array}{c}0.004 \\
(0.033)\end{array}$ & $\begin{array}{l}-0.012 \\
(0.006)\end{array}$ & $\begin{array}{c}-0.020^{* *} \\
(0.004)\end{array}$ & $\begin{array}{l}-0.001 \\
(0.006)\end{array}$ & $\begin{array}{c}0.007 \\
(0.005)\end{array}$ \\
\hline $\begin{array}{l}\text { Sector fixed effects } \\
\text { F-statistic }\end{array}$ & $\begin{array}{c}\text { Yes } \\
2.670^{* *}\end{array}$ & $\begin{array}{c}\text { Yes } \\
3.330^{* *}\end{array}$ & $\begin{array}{c}\text { Yes } \\
2.440^{* *}\end{array}$ & $\begin{array}{c}\text { Yes } \\
2.860^{* *}\end{array}$ & $\begin{array}{c}\text { Yes } \\
1.740^{* *}\end{array}$ & $\begin{array}{c}\text { Yes } \\
2.440^{* *}\end{array}$ \\
\hline$N$ & 301 & 301 & 301 & 301 & 301 & 301 \\
\hline
\end{tabular}

All models are estimated using OLS. The outcome variable in Models 1 and 2 is the number of peer business relationships to other participants from the same class that each entrepreneur formed six weeks after the training program. The outcome variable in Models 3 and 4 is the proportion of all relationships formed that exhibit skill complementarity. The outcome variable in Models 5 and 6 is the Herfindahl index of concentration among ethnic groups of the relationships formed. Constant is estimated in all models but not reported. Robust standard errors, clustered at the training class level are in parentheses. $* * p<0.01$, * $p<0.05$ 


\section{APPENDIX F: Estimating models without control variables}

Given that the empirical strategy for this paper relies on a randomization of the treatment and that this randomization was successful according to Table B1, the models estimated in Tables 3, 4 , and 5 do not need the inclusion of any control variables. Moreover, the inclusion of control variables can run the risk of overfitting the regression models. We estimated all the regression models without the inclusion of any additional control variables, to make sure the results were not driven by the inclusion of control variables. Tables F1, F2, and F3 replicate Tables 3, 4, and 5 from the paper, respectively. These tables show that the statistical significance and the substantive importance of the effects do not change with the exclusion of control variables.

Table F1: Regressions explaining the number of cooperative words chosen and information exchanged without control variables

Cooperative perception Information exchange

(1)

\begin{tabular}{lcc}
\hline & & \\
Communication practices & $0.108^{* *}$ & $1.000^{* *}$ \\
& $(0.040)$ & $(0.213)$ \\
$N$ & 301 & 301 \\
\hline
\end{tabular}

Models estimated with negative binomial regressions. The outcome in Model 1 is the number of cooperative words chosen, while the outcome variable in Model 2 is the number of words written during the networking session. Robust standard errors clustered at the training class level in parentheses. ${ }^{* *} p<0.01, * p<0.05$

Table F2: Regressions estimating the number of relationships formed, proportion of relationships formed that are skill complementary, and ethnic concentration of relationships formed without control variables

$\begin{array}{ccc}\begin{array}{c}\text { Relationships } \\ \text { formed }\end{array} & \text { Skill } & \text { Ethnic } \\ \text { complementarity } & \text { concentration }\end{array}$

(1) (2)

(3)

\begin{tabular}{lccc} 
Communication practices & $\begin{array}{c}0.755^{*} \\
(0.278)\end{array}$ & $\begin{array}{c}0.667^{*} \\
(0.276)\end{array}$ & $-0.089^{*}$ \\
& & & $(0.042)$ \\
$N$ & 301 & 301 & 301 \\
\hline
\end{tabular}

Model 1 is estimated using a negative binomial regression because the outcome variable is the number of relationships formed. Models 2 and 3 are fractional logit regressions. The outcome variable in Model 2 is the proportion of relationships formed that are skill complementary and in Model 3 it is the Herfindahl index of concentration of ethnicities in new relationships. Robust standard errors clustered at the training class level in parentheses. ${ }^{* *} p<0.01, * p<0.05$ 
Table F3: Difference-in-differences models estimating entrepreneur profits last month, without control variables

Communication practices X Post-treatment period $0.584 *$

Communication practices

$-0.610^{* *}$

$(0.212)$

Post-treatment periods $-0.078$

$(0.190)$

$N$

812

The outcome variable is logged profits last month and the regression model is OLS. Standard errors clustered at the training class level are in parentheses. $* * p<0.01, * p<0.05$ 


\section{APPENDIX G: Alternative measure of tie formation}

In Table G1 we replicate the result that exposure to communication practices leads to increases in the number of peer business relationships formed using an alternative measure of relationship formation. In Models 1 and 2 of Table 4 of the paper we used the number of co-participant entrepreneurs that each entrepreneur met up with or spoke to on the phone as an indication of a relationship. In Table G1 we use the number of business cards that each entrepreneur received by the end of the training program. Business cards have been used to measure relationship formation in other studies of entrepreneurs (e.g. see Vissa 2011) and it helps to provide additional validation of a key outcome in this study. As Table G1 shows, Models 1 and 3 include the treatment variable, which is positive and statistically significant. It is worth noting that the sample size is slightly smaller because during the field experiment the handing out of personalized business cards to participants failed in the first class that was taught, as a result we lost those observations.

Table G1: Regressions estimating the number of business cards received

\begin{tabular}{lccc}
\hline & $(1)$ & $(2)$ & $(3)$ \\
\hline \multirow{2}{*}{ Communication practices } & $0.732^{* *}$ & & $0.624^{* *}$ \\
& $(0.203)$ & & $(0.163)$ \\
& & 0.050 & 0.044 \\
Ewe ethnicity & & $(0.068)$ & $(0.054)$ \\
& & 0.067 & 0.047 \\
Female & $(0.065)$ & $(0.069)$ \\
& & -0.022 & 0.030 \\
Completed primary school & & $(0.087)$ & $(0.069)$ \\
& & 0.019 & $0.019^{*}$ \\
Employees (log) & $(0.013)$ & $(0.008)$ \\
Firm age & & -0.001 & -0.006 \\
& & $(0.006)$ & $(0.007)$ \\
Management practices score & & 0.188 & 0.151 \\
& & $(0.194)$ & $(0.165)$ \\
Class size & & $0.097^{* *}$ & $0.060^{*}$ \\
& & $(0.029)$ & $(0.027)$ \\
$N$ & & & \\
& & 271 & 271 \\
\hline
\end{tabular}

The outcome in all models is the number of business cards received from other participants in the same business training class. The models were estimated using negative binomial regressions. Robust standard errors clustered at the training class are in parentheses. ${ }^{* *} p<0.01, * p<0.05$ 


\section{APPENDIX H: Testing for effects on gender diversity}

Research on gender and entrepreneurship has stressed the differences in women entrepreneurs' ability to form new and diverse business relationships. Given this, a theoretically relevant dimension of diversity for entrepreneurs' portfolios of relationships is gender. Since our experimental treatment is theorized to affect the ethnic diversity of relationships, it is worth exploring whether it also affects the gender diversity of entrepreneurs' relationships. Table $\mathrm{H} 1$ tests this by estimating the effect of communication practices on the concentration of entrepreneurs' new relationships by gender. The effect of the treatment is negative, which aligns with out theoretical prediction that the treatment should make relationships more diverse. However, it is not statistically significant. This could be because there were not enough women entrepreneurs participanting or that gendered cultural beliefs about entrepreneurship are so deeply entrenched that the treatment was not strong enough to have an effect. In either case, this is an important question for future research to pursue further.

Table H1: Regressions estimating the effect of communication practices on the gender diversity of relationships formed

(1) (2)

Communication practices

Ewe ethnicity $-0.406$ $-0.400$

$(0.396)$ $(0.416)$

Female $-0.915^{*}$ $-0.963^{*}$

Completed primary school $-1.147^{*}$ $-1.173^{*}$

Employees $(\log )$

$(0.516)$

0.046

Firm age

$-0.015$

Management practices score

$-0.254$

$-0.288$

(0.448)

(0.427)

Class size

$-0.182$

$-0.166$

(0.101)

(0.097)

N

301

301

All models estimated using fractional logit regressions. The outcome variable is the gender concentration of the relationships formed. Constant included but not shown in models. Robust standard errors in parentheses, clustered at the training class level. $* * p<0.01, * p<0.05$ 


\section{APPENDIX I: Presentation slides for the treatment}

Below we share the slides that were developed by the instructors and the authors to lead the discussion on communication practices. We preserve the original French used in the teaching to avoid potentially ambiguous translations.

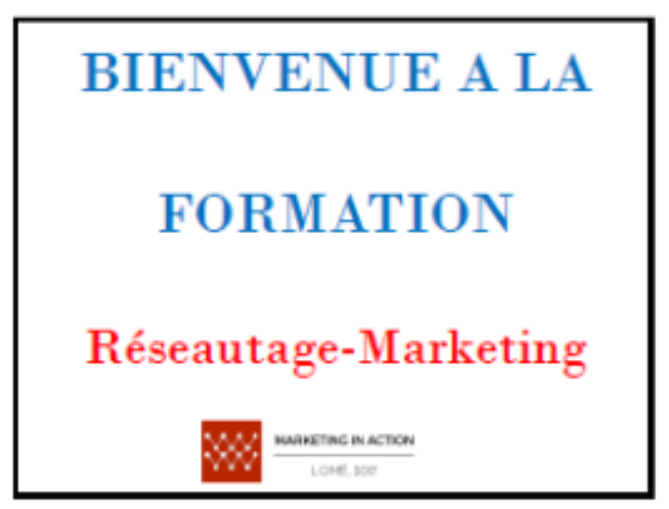

\section{MÉTHODOLOGIE:}

«GÉREZ MIEUX VOTRE

ENTREPRISE (GERME) "
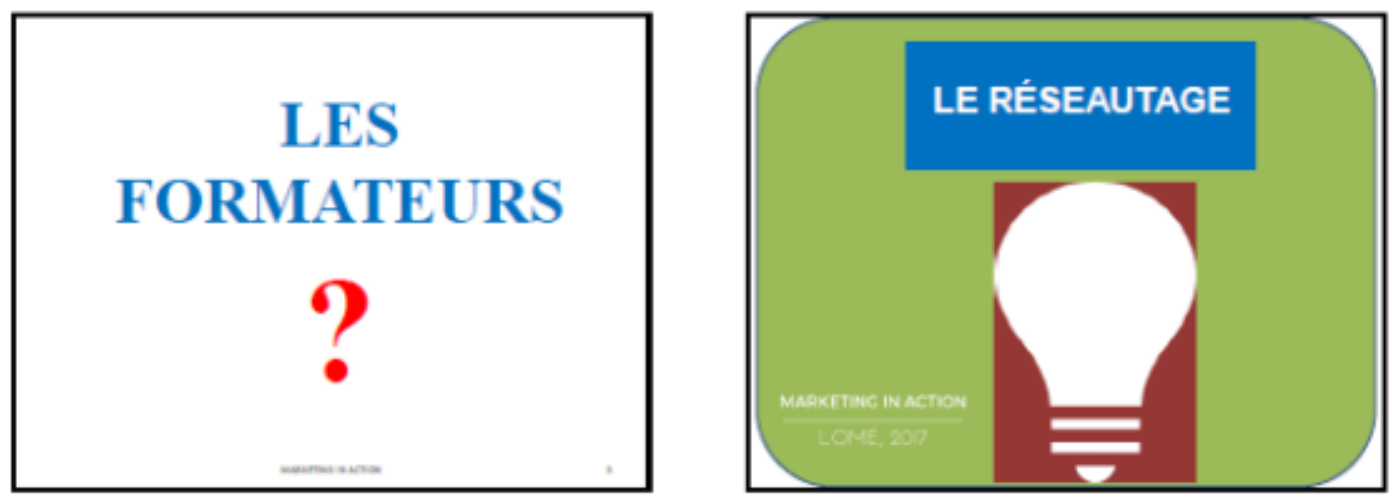

QU'EST-CE QUE LE

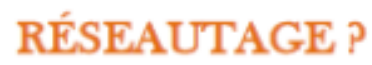


Le réseautage permet de s'ouvrir et d'aller à la rencontre de personnes nouvelles, de discuter avec eux de notre entreprise, et de les écouter parler de leur entreprise.
Chaque entrepreneur fait face à une multitude d'obstacles, qu'un grand réseau de contacts rend plus facile à surmonter.
Le processus fondamental de réseautage implique les éléments clés suivants:

- Rencontrer de nouvelles personnes

- En apprendre plus sur eux

- Leur parler de vous

- S'entre-aider a atteindre des objectifs professionnels en partageant des connaissances, des ressources, du temps, de l'énergie et des amis.

- Garder le contact et maintenir la relation
S'engager dans le réseautage mène au développement d'une relation personnelle fondée sur la confiance mutuelle et une affection mutuelle.

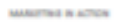

\section{Exemple:}

- Kodjo assiste a un événement pour les jeunes entrepreneurs anime par une association locale a but non lucratif a Lome. Lors de tevenement, al y a beaucoup de gens - des entrepreneurs, des fonctionnaires, des dirigeants, entre autres - la plupart descuels Kodjo n'a jamais rencontre auparavant. Lors dune présentation, Kodjo est assis a cotte dEphrem, un autre jeune entrepreneur. Meme si cela semble un peu difficile, Kodjo dit bonjour a Ephrem et se presente. II s'avere qu'Ephrem est aussi un jeune entrepreneur. Ils commencent a parler de leurs entreprises respectives et les defis auxquels ils font face.
- Il s'avère quils partagent de nombreuses expériences communes quant au démarrage fune entreprise. Ils en discutent et Kodjo se sent heureux davoir rencontré quelquiun qui connait les mêmes obstacles. Ils décident de rester en contact et de contimuer de discuter des enjeux auxquels ils font face en tant quientrepreneurs. Kodjo enregistre le muméro d'Ephrem dans son téléphone. Plus tard dans la journée, il envoie un SMS à Ephrem pour le remercier. Cela assure églement qu'Ephrem aura ses coordonnées, sil les a besoin pour entrer en contact. 
COMMENTAIRE SUR LE COMPORTEMENT DE KODJO?
Comment le réseautage peut aider à atteindre des objectifs en tant qu'entrepreneur.

\section{A. L'EFFET BOOMERANG}

$\mathrm{Si}$ vous prenez linitiative de donner, de participer et de contribuer a de nouvelles connaissances, les bénéfices vous reviendront sans doute, meme s'ils ne reviennent pas nécessairement immédiatement.

\section{B. Élargir l'assiette fiscale}

En mettant les gens en contact les uns avec les autres, en donnant de votre temps et de votre expertise et en les partageant librement, vous contribuez au succès des autres, ce qui élargit l'assiette fiscale et qui est bénéfique pour tous. vos chances de succès.

\section{AVANTAGES IMMÉDIATES} DU RÉSEAUTAGE

1-Accès à de nouvelles informations

Des nouvelles connaissances établies avec le réseautage peuvent nous foumir des informations fiables et importantes sur des opportunites que nous ne connaissions pas auparavant.
Ils peuvent nous informer de possibilités de financement, de concours ou de foires auxquelles on peut participer. De plus, ils peuvent également fournir des informations sur le marché, comme, par exemple, des informations sur les prix de nos concurrents ou les produits de fournisseurs. 


\section{Accéder à la connaissance}

Souvent, les personnes dans notre réseau possèdent des connaissances approfondies sur une variété de sujets qui peuvent nous être très utiles à différents moments.

\section{Accéder à des conseils}

Lorsque vous connaissez un grand nombre de personnes, vous pouvez leur demander des conseils et des commentaires sur votre entreprise. Le plus de personnes que vous connaissez, le plus probable il sera que vous obtiendrez un conseil utile, et en plus, il est probable que quelquiun proposera une amelioration importante

\section{Accédez aux références}

Des nouvelles connaissances peuvent vous présenter a des gens que vous n'auriez pas pu rencontrer autrement. Ceux-ci pourraient être des personnes dont vous n'avez pas entendu parler auparavant ou ils pourraient etre bien connus mais difficile a contacter.

\section{Accéder à du soutien émotionnel}

Le phus grand de nombre de gens avee qui vous avez une selation de confiance, le plus vous serez on position dobtenir du soutien pour wotre entreprive. Ce soutien peut coaduire ì de aouveaux clients pour wotre ontreprise, mais al pourrait également inchure des déclarations de soutien pour wotre entreprive auprès de dirigeants locaux qui sont bien respoctés. Ea phus, ces personnes peuvent fournir un soutien émotionnel et vous encourager ì poursuive votre travail, malgró toutes les defficultés que wous rencontrerez.

\section{COMMENT CONSTRUIRE UN RESEAU PUISSANT.}

\section{Faire du réseautage une habitude}

avez de bonnes relations, le plus possible il serra que certains d'entre eux vous foumissent des ressources utiles. Par exemple, pendant une période de difficultés, ils pourraient vous fournir un pret ou vous preter une pièce mécanique dont vous avez besoin. 


\section{2. Échanger des informations}

Le partage dinformations cree la base dune discussion. Accorder une attention particulière a ce que les autres disent; écouter attentivement sera la clé, qui vous permettra de poser des questions de suivi engageantes. Poser les bonnes questions conduit alors a la decouverte dinformations vraiment utiles que dautres peuvent vous fournir.
3. Établir la confiance avec les gens que vous rencontrez

Le véritable réseautage consiste à trouver des façons à mener ceux qui font partie de notre réseau à la réussite. Il sagit de travailler fort pour donner aux autres plus que vous obtenez. Les relations sont solidifices par la confiance. Vous grgnez la confiance en ne demandant pas ce que les gens peuvent faire pour wous, mais ce que vous pouvez faire pour eux. Autrement dit, la monnaie du vrai réseautage n'est pas la cupidité, mais la générosité.
Les étapes pratiques de la construction d'une nouvelle connexion pour notre réseau.

\section{Identifier de nouvelles personnes à} rencontrer

La première étape consiste à réfléchir aux types de personnes qui pourraient vous être utiles a lavenir.

Il faut donc spécifier mentalement les types de personnes que vous devriez viser a rencontrer.
-

Il est important que vous
rencontriez ces personnes
avant que vous en ayez
besoin. Vous ne devriez pas
tendre la main seulement
quand vous avez besoin de
leur aide.

Pour être en contacte avec eux; commencez avec une liste de toutes les personnes que vous connaissez déjà, leur travail, et leurs emplacements. Puis, réfléchissez à la façon dont ils pourraient vous connecter aux personnes que vous souhaitez.

\section{Rencontrer quelqu'un pour la première fois}

Rencontrer quelqu'un pour la première fois n'est pas facile, il ne suffit pas de dire simplement aux gens ce que vous faites, vous devez également les garder intéressés. Pour ce faire, il est important de créer une conversation qui est mémorable et engageante. 
Ecoutez ce qu'lils ont à dire. Plus vous mettrez lautre personne à l'aise, plus ils seront enclins à avoir une impression positive de vous. Souvenez-vous que les gens aiment parler d'eux-mêmes, donc poser des questions réfléchies et ouvertes telles que, "Quel projet vous tient le plus à coeur? : Cela vous permet de comprendre ce qui passionne cette personne.
Pour surmonter la difficultí líe aux premières rencontres, il est utile d'awoir un seript organisé comme suit:

a) Indiquez la situation. Il est logique quavant de pouvoir parler de façon persuasive, c'est-à-dire avant de parler d'une position de passion et de connaissances personnelles, vous devez savoir où vous vous tenez. b) Communiquez vos sentiments. Nous minimisons linfluence des emotions dans nos contacts quotidiens, en particulier dans le monde des affaires. On nous dit que la vulnérabilité est une mauvaise chose et nous devrions être prudents de révéler nos sentiments. Mais nous gagnerons du confort en utilisant les mots -je me sens" avec les autres, et nos rencontres prendrons de la profondeur et de la sincérité. Vos émotions sont un don de respect et de bienveillance a vos auditeurs.

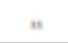

\section{Suivi}

- Lorsque vous rencontrez quelquiun avec qui vous voulez etablir une relation, faites une petite étape supplementaire pour vous assurer quil ne vous oubliera pas : le suivi. S'assurer qu'une nouvelle connaissance conserve votre nom (et limpression favorable que vous avez créée) est un processus que vous devriez mettre en mouvement juste apres votre rencontre. c) Utilisez une question ouverte. Une demande exprimée en interrogation - a laquelle on ne peut répondre par oui ou par non - est moins menaçante. * Comment vous sentez-vous envers ce sujet ? ", « Comment résoudre ce probleme ? :, Avec une suggestion ou une question ouverte, vous invitez lautre personne a travailler vers une solution avec vous.
- Chaque fois que vous rencontrez quelqu'un, assurez-wous diobtenir un courriel, un numéro de téléphone ou une adresse et de l'enregistrer correctement. Les cartes daffaires sont une merveilleuse façon de vous procurer cette information, ne soyez pas timide den demander une et de donner la vôtre. Ensuite, donnez-wous entre douze et vingt-quatre heures apres la rencontre pour le suivi. Vous pouvez envoyer un SMS, un message WhatsApp, un o-mail ou même une lettre par la poste. 
Voici quelques rappels de ce qu'il faut inclure dans vos suivis:

a) Exprimez toujours votre gratitude.

b) Assurez-vous dinchure un elément intéressant sur wotre réunica ou conversation - une blague ou un moment partage dhumour.

c) Réafirmez les engagements que wous avez pris tous les deux.

d) Soyez bref et pertinent. a) Toujours adresser la note de remerciement i la personase par soe som.

A) Ubiliser le courrier électronique et le sourrier Postal La combisaison ajoute une touche personanaliee.

y) La rapidité est essentiolle. Euvojez-los das que possible xprès la réunion ou lentrevue.

h) Beaucoup do gens attendeat les vacances pour dire merci. Pourquoi attendre? Vos mivis seroat plas opportuns, plus appropriés, ot Ion sen souviendra certainement mieux.

J) Notubioz pas do faire un suivi avee cous qui ont ag" comme intermédiaire. Laissez-leur savoir comment la coaversation cest pastó, ot exprimer votre appróciation ports leur aide.

7) Faire du suini une habitude. Rendezie automatique.

\section{MERCI}

soyez actif

BONNE CHANCE A TOUS !!! 


\section{APPENDIX J: Survey questions}

The variables used in our analyses relied on survey questions that were administered to entrepreneurs participating in the field experiment, as described in Appendix A. Below are the survey questions that correspond to data used in the construction of variables used in the analyses for Tables 3,4 , and 5 .

\section{Entrepreneur gender ("female")}

\section{Q13 Sexe: \\ Masculin \\ Féminin}

\section{Ethnic group ("Ewe ethnicity")}

Q14 Quelle langue parlez-vous à la maison?

O Ewe

F Français

O Kabye

O Kotokole

O Autre:

\section{Entrepreneur education ("Completed primary school")}

\section{Q16 Quel est votre niveau scolaire?}

O Aucune scolarité complète

O École primaire complète (CEPD)

Collège complet (BEPC)

O Lycée complet (BAC)

O Brevet de technicien supérieur (BTS)

O Licence universitaire

O Master ou Doctorat

\section{Year the business was started ("Firm age")}

Q33 En quelle année avez-vous commencé votre entreprise?

\section{Employees in entrepreneurs' business ("Employees (log)")}

Q44 Maintenant, je vais vous poser quelques questions concernant le nombre d'employés travaillant dans votre entreprise actuellement. (Par emploi à temps plein je veux dire qu'on travaille 8 heures par jour ou plus.)

\begin{tabular}{|c|c|}
\hline $\begin{array}{c}\text { Combien d'employés à temps plein avez- } \\
\text { vous? }\end{array}$ & Nombre total \\
\hline $\begin{array}{c}\text { Combien d'employés à temps partiel avez- } \\
\text { vous? }\end{array}$ & $\begin{array}{c}\text { Combien de stagiaire ou apprenti avez-vous } \\
\text { employé? }\end{array}$ \\
\hline
\end{tabular}




\section{Management practices score items}

Q148 Dans les derniers 6 mois avez-vous:

Q50 Visité un de vos concurrents pour voir quel prix ils demandent?

O Oui (1)

Non (2)

Q51 Visité un de vos concurrents pour voir quels produits ils vendent?

O Oui (1)

Non (2)

Q52 Demandé à vos clients existants s'il y a d'autres produits qu'ils aimeraient que vous vendiez ou produisiez?

O Oui (1)

O Non (2)

Q53 Parlé avec au moins un ancien client pour savoir pourquoi ils ont cessé d'acheter de votre entreprise?

O Oui (1)

Non (2)

Q54 Demandé à un fournisseur quel produits se vendent bien dans votre secteur?

O Oui (1)

O Non (2)

Q57 Au cours des trois derniers mois, avez-vous utilisé une offre spéciale pour attirer des clients?

O Oui (1)

Non (2)

Q56 Au cours des trois derniers mois, avez-vous utilisé une forme de publicité?

O Oui (1)

O Non (2)

Q59 Avez-vous fait quelque chose pour mesurer l'efficacité de la publicité?

O Oui (1)

Non (2)

Q58 Au cours des trois derniers mois, avez-vous tenté de négocier avec un fournisseur pour un meilleur prix sur vos matières premières?

O Oui (1)

O Non (2) 
Q69 Au cours des trois derniers mois, avez-vous comparé le prix ou la qualité offerte par d'autres fournisseurs à celle de votre fournisseur actuel ?

O Oui (1)

Non (2)

Q66 Est-ce que il y a eu un moment où l'entreprise n'a pas eu assez de stock ou de matières premières pendant les 3 derniers mois?

O Oui (1)

Non (2)

Q62 Gardez-vous des documents commerciaux écrits?

O Oui (1)

Non (2)

Q61 Enregistrez-vous chaque achat et vente faite par l'entreprise?

O Oui (1)

Non (2)

Q76 Pouvez-vous utiliser vos documents pour voir facilement combien d'argent est disponible à votre entreprise à tout moment?

O Oui (1)

Non (2)

Q75 Utilisez-vous régulièrement vos documents pour savoir si les ventes d'un produit particulier augmentent ou diminuent d'un mois à l'autre?

O Oui (1)

O Non (2)

Q74 Avez-vous calculé le coût de production de chacun de vos produits principaux?

O Oui (1)

O Non (2)

Q73 Savez-vous lesquels de vos produits vous apportent le plus profit par unité?

Oui (1)

Non (2)

Q72 Avez-vous un budget écrit, qui vous indique combien vous devez payer chaque mois pour le loyer, l'électricité, l'entretien de l'équipement, le transport, la publicité, et d'autres dépenses de l'entreprise?

O Oui (1)

O Non (2)

Q80 Si vous vouliez demander un prêt bancaire, et vous étiez demandé de fournir des documents pour montrer que vous avez assez d'argent chaque mois pour rembourser un prêt, est-ce que vos documents vous permettraient de le démontrer à la banque?

Oui (1)

Non (2) 
Q79 Examinez-vous la performance financière de votre entreprise et analysez-vous les points à améliorer chaque mois?

O Oui (1)

O Non (2)

Q78 Avez-vous un objectif pour les ventes au cours de la prochaine année?

O Oui (1)

O Non (2)

Q77 Est-ce que vous comparez votre performance à cette cible au moins une fois par mois?

O Oui (1)

Non (2)

Q82 Avez-vous fait un budget des coûts auxquels votre entreprise fera face l'an prochain?

O Oui (1)

O Non (2)

Q83 Avez-vous fait un compte de résultats?

O Oui (1)

Non (2)

Q131 Avez-vous fait un tableau de flux de trésorerie au cours de l'an passé?

O Oui (1)

O Non (2)

Q132 Avez-vous fait un bilan annuel pour l'an passé?

O Oui (1)

Non (2)

Q133 Avez-vous fait l'état de vos résultats / dépenses annuelles?

O Oui (1)

O Non (2)

\section{Entrepreneurs' business performance ("Profits last month, log")}

Q110 Quelle était la valeur de vos bénéfices en FCFA au cours de

\section{La semaine dernière (1)}

Valeur estimée (1) 


\section{Interactions with co-participants ("Relationship formation")}

Q0.2 Depuis la formation, est-ce que vous avez rencontré des personnes qui ont fait la formation avec vous ?

Oui

O Non

Q0.3 Si oui, s'il vous plait nommez-les :

Personne 1

Personne 2

Personne 3

Personne 4

Personne 5

Personne 6

\section{Cooperative words}

S'il vous plaît, encerclez les $\mathbf{5}$ mots qui décrivent le mieux la formation que nous avons fait :

\begin{tabular}{|c|c|c|}
\hline Concurrence & Rivalité & Connecter \\
\hline Discuter & Echanges & Abattre \\
\hline Amitié & Partenariat & Compétition \\
\hline Rapporter & Collaboration & Bénéfices \\
\hline Association & Pouvoir & Adversaire \\
\hline Maximiser & Aider & Eloigner \\
\hline Communication & Partage & Gagner \\
\hline Dominer & Alliance & Confiance \\
\hline
\end{tabular}




\section{Skill entrepreneur wants to learn ("Skill complementarity")}

Dans l'espace ci-dessous, veuillez décrire une chose que vous aimeriez améliorer dans votre entreprise au cours des deux prochains mois:

Veuillez choisir s'il s'agit d'un changement dans:

- Marketing

- Comptabilité

- Financement

- Tenue des dossiers

- Recherche de fournisseurs

- Achat de stock

- Employés et embauche

- Planification pour l'avenir 


\section{REFERENCES}

Charmaz, K.

2014 Constructing Grounded Theory. Thousand Oaks, CA: Sage.

Small, M. L.

2009 "How many cases do I need?' On science and the logic of case selection in fieldbased research." Ethnography, 10: 5-38.

United Nations Development Programme

2017 Human Development Indicators: Togo. New York, NY: Human Development Reports.

World Bank

2018 World Development Indicators. Washington, DC. 